9. Whereas, the acquisition and compilation of reliable information on wildlife populations is rendered difficult through lack of knowledge of basic methods of game inventory on the part of sub-professional personnel;

Resolved that representations be made to the Heads of all Canadian Ranger Schools to the end that the curricula of such schools include instruction in the basic principles of game inventory sufficient to enable graduates of such schools to prepare adequate reports on game abundances.

10. Whereas cutting operations have on many occasions in the past caused damage to game range and recreational values;

And whereas in most instances such damage could be avoided by adequate advanced planning:

Resolved that the requirements of forest wildlife and recreation be taken into consideration in the formation of working plans.

11. Whereas the establishment of a population of beaver is known to provide permanent water in areas where it may not have previously existed; And whereas various game administrations are in the process of augment. ing beaver supply to increase fur production:

Resolved that operators give every assistance to the cultivation of beaver populations on timber limits for the purpose of water storage as a fire protection device.

12. Resolved that the appreciation of the Society be expressed to the members of the Maritime Section and the Annual Meeting Committee for their efforts in making the arrangements for the meeting which have contributed largely to its success.

13. Resolved that the Society express its appreciation of the hospitality provided by the Hon. R. J. Gill, Minister of Lands and Mines of the Province of New Brunswick.

14. Resolved that the Society express its appreciation to Dr. A. W. Trueman, President of the University of New Brunswick, for the outstanding address presented at its Annual Meeting.

15. Resolved that the thanks of the Canadian Society of Forest Engineers be tendered to Watson-Jack Limited for the courtesies extended on the occcasion of the 40th Annual Meeting of the Society.

16. Resolved that the thanks of the Canadian Society of Forest Engineers be tendered to the New Brunswick Bureau of Information and Tourist Tra. vel and the Press and Radio News Service for publicity on the occasion of the 40th Annual Meeting of the Society.

17. Resolved that the thanks of the Canadian Society of Forest Engineers be conveyed to staff and management of the Lord Beaverbrook Hotel for services provided.

18. Resolved that the thanks of the Canadian Society of Forest Engineers be conveyed to the exhibitors who exhibited displays.

\title{
REPORTS OF STANDING COMMITTEES, 1947 FARM WOODLOT
}

Owing to the fact that a Secretary was not appointed for this committee until late in November, 1947, it has been difficult to secure reports from the members, and as a result this report is sketchy and does not cover the entire field. 


\section{Quebec Department of Lands and Forests, Forestry EXTENSION Bureau \\ by $R$. Delisle}

The technical personnel engaged in extension work at this time consists of twelve men-one director with eleven men working under him. These men have been very active, and have in the course of their work visited many woodlots in an advisory capacity. Lectures, radio and the press have been widely used to promote a proper forest mentality among woodland owners and to show them how to handle their forest lands.

With the collaboration of the Scierie-Ecole of Duchesnay and The Youth Training Service, the Bureau is going to offer to woodland owners and woodland owners' sons, 16 to 30 years old, a course in elementary silvicul. ture. To be given at Duchesnay, this course will last fifteen days, and will deal with saw filing, log and lumber scaling, lumber seasoning, forest pro ducts marketing, but chiefly with woodlot and sugar bush management. Demonstration lessons in the Duchesnay forest will alternate with class lessons. Arrangements are for three sessions and fifty attendants per ses sion.

\section{ONTARIO}

In 1947 there were two notable developments in farm woodlot forestry in Ontario.

The first of these was the widespread adoption through legislation by Southern Ontario counties of the opportunity of controlling the cutting of trees on privately owned lands. Many counties have enacted by-laws which are now in force, controlling the cutting of trees. Each county council has appointed men to enforce these by-laws and to inspect properties to check on the cutting operations. There have been several prosecutions in the courts, with offenders being fined up to $\$ 250.00$ for a breach of the regulations.

It would appear that the public is whole-heartedly in favour of these restrictions as a means of preserving our woodlots. Although all the regulations drawn up to date are based on a diameter limit, they are serving to make the public realize that some restrictions are necessary. It is hoped that in time the regulations will be changed to allow controls which will permit the use of better forestry practices. It is quite common for the by-law enforcement officers to consult the Zone or District Foresters, and in this way contacts are frequently established with woodlot owners, which otherwise would not be made.

The second major development which concerns the farm woodlot was the publication of the report of the Ontario Royal Commission on Forestry. This report, compiled by Major-General Howard Kennedy, dealing with the complete picture of forestry in Ontario, devotes much space to the farm woodlot situation. A brief summary of the section of the Report dealing with woodlots is presented below:

There are five factors which are the cause of the present unsatisfactory situation with regard to woodlots: 
(1) Owner's indifference and lack of knowledge,

(2) Cost of fencing,

(3) Assessments,

(4) Drainage schemes,

(5) Lack of marketing information.

(1) Woodlot owners may be divided into two classes, a minority who are interested in their woodlots for various reasons, and the great majority who are not interested, but who happen to have woodlots. How to convince this latter group of the potentialities of the woodlot under proper management is one of the most difficult problems awaiting solution. Few are aware of the assistance that is available to them.

There is urgent need for the inauguration of immediate restorative measures, as well as for the control of the exceedingly destructive methods practised by so many operators who purchase and remove timber from Ontario's woodlots. There is a pitifully small minority of woodlot owners who manage their forests wisely and well, and who are reaping a rich harvest from them. It is estimated that this group includes less than two per cent of the woodlot owners.

Pasturing of animals in woodlots is the most widesspread abuse found, and if this practice could be eliminated, more than half the battle to save Ontario's woodlots would be won. Forestry and pasturage cannot succeed on the same piece of ground as diametrically opposite conditions are necessary for each.

(2) The cost of fencing and its maintenance is a big factor in the deterioration of the woodlot. It was recommended that the Province and the counties share in a programme designed to provide half the cost of fencing the woodlots or repairing (to a proper standard) the woodlot fences of any property owner willing to enter into an agreement with the Depart. ment of Lands and Forests. Such an agreement should provide for proper care and perpetuation of existing forests or new plantations, and must carry the approval of the District Forester.

(3) Present legislation concerning assessment practices on forest land may easily result in discouragement of sound forestry. Woodlands may at times be assessed at a higher rate than the best farm lands. This is taxing the crop, and is not taking into account the number of years that were required to produce that crop.

It was recommended in the Report that an equalization of taxation be undertaken, with a reduction in taxes on lands already carrying good forests, and an increase on lands which are barren or near-barren but which are potential forest sites and which would develop their highest economic and community utilization if retained for or returned to the growing of trees.

It was also stated that there is little inducement under the present exemption practices for a man to plant and care for a forest which requires several decades before yielding economic returns. It was recommended that the Province and the counties jointly explore some method by which a yearly bonus may be paid on young forest stands until they reach the production stage, provided they are cared for in a manner approved by the District Forester. 
(4) In recent years the drainage schemes which have been carried out under the provisions of the Statutes from time to time in force have proved most detrimental to woodlands in some parts of the province. In the early days drainage was necessary, and it was only natural that all drainage should be considered as beneficial. Under the Statutes now in force the expense is to fall only on the owners of lands which are benefitted. Nevertheless the belief seems to persist that if land is drained, benefit must ensue. No consideration is given to the fact that the drain may imperil the life of forests along its course by the lowering of the water table. No provision is made for compensation to owners whose lands are damaged, unless the damage is caused by flooding. Most drainage projects follow lower ground where most of the remaining trees in the area are to be found, thus resulting in damage to the few remaining woodlots in the area.

A complete and early review of the Municipal Drainage Act and The Ditches and Watercourses Act is recommended with the object of insuring:

(a) that no drainage project will be undertaken until its probable effect upon the community as a whole has been considered by a board of referees composed of judicial and engineering personnel, as well as practical farmers, and the approval of such board obtained.

(b) that no single landowner or small group of owners may be enabled to force an unwanted and even detrimental drainage scheme on neighbouring owners without their consultation and consent;

(c) that the costs of the work will be equitably distributed among the landowners actually benefitted;

(d) that provision shall be made for payment of compensation to those injuriously affected, and

(e) that Municipalities shall have power to expropriate areas which it is proposed to drain, when the welfare of the community requires that the area in question should be maintained in its existing state.

(5) A relatively quick solution of the present serious problem of woodlot devastation could be furnished by assisting woodlot owners to market their products. A ready, reliable and profitable outlet for the products of the woodlot would engender in the minds of the great mass of owners an interest in the long-range possibilities of scientific forest management. Due to lack of knowledge on the part of farmers concerning location of markets, most of the potential supply of timber on Ontario's woodlots never gets into its proper economic channel.

A recommendation suggests that the Government set up a Marketing Division within the Department of Lands and Forests and that the services rendered by the District and Zone Foresters should be widely expanded. Necessary advice as to cutting methods, what and when to cut, etcetera, should be supplied by the government.

These are the major points covered in the Report in connection with woodlots. There are, however, several other points which should be mentioned here. It was felt that if the signs indicating demonstration woodlots gave more comprehensive information regarding what was being demonstrated, including rate of growth per acre, content or value at stated intervals, the 
date at which young stands will come into production, etcetera, many more people would stop and inspect the notices and the forest.

Some form of fire protection on heavily wooded lands in Southern On. tario was suggested. This should be carried on in conjunction with the Department of Lands and Forests and the municipalities. Fire fighting equip. ment should be purchased, and held available to cope with a crisis when it arises.

It was estimated that the woodlots in Southern Ontario could at present produce at least 25 cubic feet per acre per year, of which there would be 60 board feet of lumber per acre per year. This is equivalent to a total annual production from all Southern Ontario woodlots of 110,000,000 feet board measure of lumber and some 300,000 cords of fuel-wood and pulpwood, in addition to the fuelwood from limbs, thinnings and sawmill waste. It was stated that with sound silvicultural methods, in thirty years, this could be increased to $184,000,000$ feet board measure of lumber, and 370,000 cords of fuelwood and pulpwood, plus the by-products.

We in Ontario believe that many worthwhile recommendations are contained in this report, and feel that, if in time they can be adopted in some manner, our woodlots can then be managed more wisely and more economically. General Kennedy also suggests that it should be provincial legislation which controls the cutting of trees on private lands, and that trees to be cut should be marked by trained personnel.

Before these suggested changes can be brought about, it will be necessary to greatly increase the staff of foresters maintained in the field by the Department of Lands and Forests. Even at present, there is a shortage of trained men, and although the staff is being increased as men are available there is room for many more foresters. A still greater staff will be necessary to implement and carry out the changes suggested in the Commission's Report, a well as to meet the growing demand on the time of the foresters now employed in the field.

Mr. A. Koroleff reports that plans are now under way to introduce into the schools of Eastern Ontario the booklet written by himself, entitled "Practical Woodlot Management." By making this available to school children, its influence will spread to the farm homes, thus helping to improve woodlot management in that area. A second edition of this booklet was issued early in 1948. This is proof of its popularity and widespread circu. lation.
I. C. Marritt, Chairman
W. A. G. Thurston, Secretary

\section{FOREST ENTOMOLOGY}

This Committce has not met as a body during the year. As usual this report is based on contributions by individual members covering developments in forest entomology in their respective territories. The Committee is grateful to Dr. L. Daviault, Director of the Forest Entomological Service in Quebec, to Messrs. R. E. Balch and W. A. Reeks of the Fredericton Laboratory, and to W. G. Mathers of the Vernon Laboratory for special contributions. 
In the present report information relative to forest insect conditions during the past year is condensed, since this information is or will be avail. able elsewhere. Emphasis is placed on the nature and trends of research studies and on developments and suggestions relative to progress in forest entomology. It is felt that this Committee should be more than a purely reporting body and should constitute a medium through which suggestions for progress in forest insect research and control can be given expression.

Important Developments Relating to Forest Entomology in Canada

The work of the Forest Insect Investigations Unit, Division of Entomology, has been expanded during the year. Since this unit is the chief agency conducting research on forest insects the recent increases in staff and facilities are gratifying. The establishment by the Dominion Department of Agriculture of a special laboratory at Sault Ste. Marie for the study and propagation of insect diseases was forecast in the 1946 report of this committee. Construction of this laboratory was started in May, 1947, and the building was closed in before winter set in. Interior construction and the installation of special equipment proceeded during the winter months, and the laboratory went into service in 1948. A nucleus of trained staff and technicians is already engaged on surveys and investigations of diseases affecting forest insects, but increased personnel will be required for the fulfilment, in the laboratory and in the field, of the functions of the new in. stitution.

The Forest Insect Control Board has continued its active support of the programme of the Unit and many of the recent extensions and improvements in the forest insect service are traceable to the support given by the Board. The Board has been strengthened by the appointment of a Prairie Provinces' representative. Forest Entomology in the Prairie Provinces is also being furthered by the formation of a regional Advisory Committee on Forest Entomology.

The established Advisory Committee on Forest Entomology and Pathology of the Canadian Pulp and Paper Association has not met during the past year but the membership of the committee has been active. A subcommittee has been studying the proper function of the Advisory Committee with a view to making recommendations as to how it could more effectively achieve its purpose. This sub-committee has also been studying the status of undergraduate and graduate instruction in forest entomology at Canadian forest schools.

Industry has shown an increasingly active interest in forest insect prob. lems. On the west coast representatives of the forest industry met with J. J. de Gryse, Chief of the Forest Insect Investigations Unit, to discuss forest insect problems, and the development of staff and facilities for adequate attack on the problems of the west coast region. The Canadian Pulp and Paper Association has published for distribution to its membership an article entitled, "Some Financial Aspects of Removal of Overmature Balsam Fir as a Budworm Control Measure"; this article reports on studies conducted in Maine. The co-operative Green River Project on management of sprucefir stands with reference to protection from the spruce budworm, has made further progress and a fifth report has been issued. During the winter of 
1946-47 pre-salvage cutting of jack pine was undertaken by the K.V.P. Company in an area in Ontario, which has been under heavy attack by the jack pine budworm.

In the field of education the interest of both government and industry is again shown. The Ontario Research Commission has made available a number of scholarships for post-graduate study in Canada, the United States and abroad. Several of these awards have been made to students of forest entomology. A number of undergraduate scholarships, open to forestry students who have been employed during the summer seasons in forest entomological investigations, have been established jointly by the Canadian Pulp and Paper Association and the Canadian Lumbermen's Association. These scholarships will encourage promising forestry students to take up forest entomology as a life work.

The training of forestry students in forest entomology has received additional support by the establishment of a Chair in Forest Entomology at the University of British Columbia. A sum of $\$ 25,000.00$ has been provided by two Vancouver firms to finance this development for a period of five years. George R. Hopping, of the Forest Insect Unit, has been granted leave of absence for the 1947.48 academic year to start a course in forest entomology. It is anticipated that the Chair will be filled on a permanent basis before the fall of 1948 .

Conditions for study in forest entomology at the University of Toronto are still inadequate. It is hoped that the investigations of the Pulp and Paper Advisory Committee, previously mentioned, will result in recommen. dations and remedial action. A proposed Ecological Centre to be established by the Ontario Research Commission would, among other things, provide facilities at Toronto for graduate students in forest entomology.

At Queen's University a graduate course in forest biology with emphasis on insects has been instituted. Facilities for field research in forest entomology are available at the Queen's Biological Station on Lake Opinicon and studies were started in 1947. Investigations in insect bacteriology are being conducted at Queen's and facilities for graduate students interested in this field are available.

\section{RESEARCH}

Spruce Budworm. Continued and expanded studies of the spruce budworm and associated species have been conducted throughout the east. The cooperative forestry and entomological studies have been continued on the Green River Project in New Brunswick. Further progress has been made. on working plans, road-building, marking of experimental cuttings, and investigations of the low-level budworm population. The development of sampling methods and the study of natural control factors have been continued.

In Quebec studies were continued at two temporary field stations established at Lake Wagoose in the Cabonga District and at Lake Gagnon in the St. Maurice Valley. The main purpose of these investigations is to secure information on the behaviour of the insect and on factors controlling 
its multiplication in two widely separated localities. Aerial surveys were again made in August to map territory most seriously affected by the budworm.

In Ontario investigations in the field ecology of forest insects-particularly the budworm-comprising population studies, natural control factors, life history and development, behaviour, genetic relationships of the forms on spruce and balsam, and on jack pine, migration and dispersal as affected by starvation and mteorological factors, and deterioration of damaged timber, have been carried out in various parts of the province. In the Algoma region a study has been made of damage caused by the spruce budworm in relation to stand composition. In the Sioux Lookout District an intensive investigation of the relationship of budworm infestation to the physiology of the balsam fir host stand has been initiated. The latter two projects should contribute materially to an understanding of the possibilities of control or prevention of budworm damage through forest management.

A survey of disease organisms attacking the spruce budworm in Ontario has shown the widespread presence of a polyhedral disease causing "wilt". This disease was observed to be exerting a considerable influence on the host populations in parts of the Cochrane and Kapuskasing Districts. A fungus disease (Hirsutella sp.) has also been found in samples of the population throughout northern Ontario.

Studies on the hybridization of the spruce budworm and the jack pine budworm have shown that crossing can occur under insectary conditions, although partial barriers to crossing exist, including differences in time of seasonal development, a chromosome difference leading to partial sterility, and mating activity at different times in the day. An area of overlapping populations of the two forms will be studied in 1948 to determine if hybridization occurs under natural conditions.

Additional experimental photography of forest areas damaged by the spruce budworm has been carried out in Ontario. An attempt is being made to determine whether photographs can be used as a reliable indicator of budworm damage. It is evident that an investigator must have special training in order to avoid misinterpretation.

In Manitoba studies have been continued on the biological control of the spruce budworm.

In the interior of British Columbia where investigations of the relation of cutting methods in spruce-balsam stands to spruce budworm hazard are underway, studies somewhat similar to those of the Green River Project are being conducted.

Jack Pine Budworm. In Manitoba and Ontario the development of the jack pine budworm outbreak is being closely followed. The role of pollen in the epidemiology of this form and the previously mentioned hybridization studies are the chief projects.

Die-back of Birch. Greater attention has been given to the die-back of birch. Through co-operation of various Dominion and Provincial Forest Insect Units the degree of die-back of yellow and white birch has been examined throughout the east. The abnormal die-back, such as occurs in the Maritimes, is 
spreading into Quebec but is not evident in Ontario. The bronze birch-borer is, however, active in Ontario and the usual deterioration of birch tops is evident in stands where the beetle is active. Detailed researches are being conducted in Nova Scotia by the forest pathologists and entomologists into the part played by the borer in initial phases of die-back and decadence, root conditions of birch, growth, and disease in relation to stand and tree conditions. The results of these studies are to be published shortly.

Dutch Elm' Disease. The Quebec Forest Insect Service is conducting detailed studies on the Dutch Elm Disease. Efforts are being concentrated on collec. tion of data concerning insect vectors of the disease. Five insect species have been studied during the year.

Studies of White Pine. A new type of investigation of white pine is being undertaken in Ontario where studies concerning resistance of this species to white pine weevil and to blister rust have been initiated. The plan is to top graft apparently resistant individuals to Scotch pine which has been planted in a weevil area. This is a long term project which will allow any inherent resistance to manifest itself. Investigations of the white pine weevil in plantations at the Petawawa Forest Experiment Station which, unfortunately, were suspended during some of the war years due to staff deficiencies, were recommended in 1947 .

The results of observations on the effect of white pine weevil on plantations in New Brunswick were published in the "Forestry Chronicle" in December, 1947.

Investigations are also in progress in Saskatchewan on the relationship of site to weevil infestation of jack pine.

Larch Sawfly. Studies on the biological control of the larch sawfly and of the effects of water levels in the swamps on sawfly populations are being continued in Manitoba. Continued investigations of the natural control of this species in the interior of British Columbia have shown that introduced parasites are exerting an effective control on the populations.

Western Hemlock Looper. Studies of the western hemlock looper infesta. tion on the Big Bend of the Columbia River in the interior of British Columbia showed that adverse weather conditions during the winter of 1946-1947 apparently caused high mortality of the overwintering eggs and was responsible for the subsidence of the infestation. In the Alberni Canal area of Vancouver Island an important new development has been the investigation in the field of diseases affecting the hemlock looper.

Mountain Pine Beetle. In the Banff National Park, where control measures were carried out several years ago, the population remains at a low level. A decline also occurred in the Leanchoil area following control work in 1946 but a further recleaning of the area has been recommended. In the Yoho National Park experiments have been initiated to test the effectiveness and practicability of the chemical injection of beetle infested trees as a substitute for the standard practice of cutting and burning.

Various other investigations are in progress throughout Canada. The control of borers in logs by means of D.D.T. sprays has received additional study in New Brunswick. Deterioration of fire-killed jack pine by wood 
boring insects is being investigated by members of the Winnipeg Laboratory. The beech scale is being studied in New Brunswick with special reference to the importance of winter temperatures and predators on the population of the scale. In British Columbia investigations of the life history, habits and natural control of the lodgepole pine needle miner are being continued, and investigations have been initiated relative to the control of the Douglas fir tussock moth and the false hemlock looper in the interior of the province. The first two of these species are frequently affected by disease.

Forest Insect SuRvey and Forest Insect Conditions

Across Canada the staff of the Forest Insect Survey, both Dominion and Provincial Units, was increased in 1947. This has made possible the collection of a greater number of samples and greater co-operation with industry. With the experience of each passing year the forest insect ranger personnel and other co-operators are increasing the value of the survey. It is becoming readily more feasible to conduct special surveys as was done in Quebec and elsewhere during 1947. In Ontario forest insect ranger cabins have been erected in seven districts, thus adding stability to the establishment of rangers in the districts. A unit of the survey has been established in Nova Scotia. On the west coast the commissioning and remodelling of a $60 \mathrm{ft}$. boat has greatly increased the scope of the survey. This intensified activity of the Forest Insect Survey throughout the different regions of Canada is yielding more detailed and useful information on the distribution and status of the more important forest insect pests.

The following list is by no means intended to present a complete picture of the forest insect condition in 1947, but rather contains information submitted to this Committee and contained in the Forest Insect Investigations Bi-Monthly Progress Reports. A complete record is of course available in the form of the Annual Report of the Forest Insect Survey.

Maritime Provinces and Newfoundland:

Spruce Budworm. In the Green River area, a several-fold increase in the larval population occurred over that of 1946 but the population is still too light to cause appreciable defoliation. There has been no increase in the very light infestation on Cape Breton Island, Nova Scotia. A single specimen was taken on Prince Edward Island. The outbreak on Bell Island, Newfoundland, has spread to the Avalon Peninsula.

Black-headed Budworm. This species has shown a population increase in northern New Brunswick and has caused noticeable to heavy defoliation of the 1947 growth of balsam fir especially in Restigouche County. The species has been abundant on the Avalon Peninsula, Newfoundland, for several years.

White-marked Tussock Moth. This species continued in abundance in the lower St. John Valley in southern New Brunswick, Nova Scotia and Prince Edward Island early in the season; but the populations of larger larvae in most localities were decimated to unimportant numbers by several parasitic insects and by a disease.

Beech Scale. This insect is slowly spreading northward towards Quebec, having been recorded in Victoria and Gloucester Counties in 1947. Killing 
of beech may be expected to continue in the more northerly areas of scale distribution, while in the southern portions of the Maritimes most of the mature beech is already dead.

Bronze Birch Borer. The greater part of the mature stands of birch in New Brunswick has already died as reported previously, and the "die-back" con. dition has spread further into Nova Scotia and Quebec. In certain parts of New Brunswick some of the surviving trees show signs of recovery and young stands have often escaped severe mortality. The hardwood stands of New Brunswick should be re-examined and a revised inventory and an up-to-date picture of hardwood regeneration obtained on which to base future management plans.

Balsam Woolly Aphid. This introduced pest of balsam fir increased in numbers in 1947 following a series of favourable winters when mortality has not been serious. Balsam fir trees as scattered specimens and in groups have been killed in the southern part of New Brunswick during the past two years and more may be expected to die in 1948 .

The introduced predator Lewcopis obscura Trag., has spread throughout all the infested parts of New Brunswick and a short distance into Nova Scotia from the points of liberation in 1935 and later. The predator has, however, not proved to be an efficient control agency due to its dependence on a rather high population of the host aphid.

Pine-Leaf Chermes. The outbreak of this insect which has continued with varying intensity for some ten years in the vicinity of Shirley in central New Brunswick increased greatly in 1947 and the injury to white pine was the most severe and widespread to date. The insect alternates in successive generations between white pine and red spruce. Twig galls are formed on red spruce, but do not cause much injury. In mixed stands of young white pine and red spruce, many of the new shoots of the white pine were killed although no trees have died to date. Red pine is not affected.

Balsam Fir Sawfly. A localized outbreak of this species has been observed in the St. Georges District, Newfoundland.

Quebec:

Spruce Budworm. The budworm continued to spread and increase in abundance in the eastern portion of its distribution. The species is generally present on the North Shore and in the Eastern Townships but at very low population levels in the latter region. Over most of western Quebec in the old infested area comprising regions of Abitibi, Temiscamingue, Kipawa and Gatineau, there was a drop in population density, but an increase in mortality of trees. The biggest population increase occurred in the Lake St. John and Saguenay Districts.

Black-headed Budworm. A notable population increase of this species was observed in several regions in the east. The centre of the infestation is along the Grand Cascapedia River in the Gaspe Peninsula where severe defoliation of balsam fir has occurred.

European Spruce Sawfly. No population increases have been recorded. Swaine's Jack Pine Sawfly. This species has caused severe defoliation of jack pine in the Clova District, Abitibi County and in certain areas trees are dying in large numbers. Some other factors are apparently involved. 


\section{Ontario:}

Spruce Budworm. The following conditions obtained in 1947:-

(1) Subsidence to endemic conditions in the area between Michipicoten Harbour on Lake Superior and the Quebec border, with some tendency for the residual population to be concentrated on white spruce rather than on balsam fir.

(2) Intensification and extension of the infestations in the area between White Lake and Abitibi Lake, stretching through the northern portion of the Sault Ste. Marie, Chapleau and Gogama Districts and the southern portions of the Kapuskasing and Cochrane Districts.

(3) An extension of the Lake Nipigon infestation beyond Long Lake, Pag. wachuan Lake and Chipman Lake in the east, with comparatively little change in the south and west.

(4) Persistence of the small infestation in the vicinity of Sioux Lookout and Hudson.

(5) Intensification, as well as extension, of the infestation in the southern portion of the Sioux Lookout District from Red Lake in the northwest, Wenasaga Lake in the northeast, Perrault Lake in the southeast, and Maynard and Ball Lakes in the southwest, with an extension to Clay Lake along the Wabigoon River.

Jack Pine Budworm. This insect persists in heavy infestation in the western portion of the Sioux Lookout District, and the southeastward movement of this infestation, combined with the southwestward movement of the spruce bud. worm infestation has created an area of overlap in the vicinity of Clay Lake, Big Canon Lake, Ball Lake, and the Wabigoon River. The infestation in the vicinity of Sultan, southeast of Chapleau, has not shown any great change but there has been some extension to the southwest. Specimens affected by wilt disease were recovered from insect samples from this area.

Yellow-headed Spruce Sawfly. Marked increases in populations of this species and destruction of black spruce have been observed in the Espanola region. Leconte's Sawfly. This species was, on the whole, not as abundant in southern Ontario as in former years.

European Pine Shoot Moth. This insect is the most destructive species affecting hard pines in southern Ontario. The species is well established throughout the southwestern counties.

The leaf mining linden beetle and the maple leaf cutter continued in abundance in the Rideau Lakes region and elsewhere. A localized infestation of the alder sawfly on alder and birch is of note, considering the present importance of this species on the west coast.

Prairie Provinces:

Spruce Buduorm-Jack Pine Budworm. The well established infestation in the Spruce Woods Forest Reserve covers the entire region with severe defoliation centering in the western part. A light, scattered infestation is indicated along the west shore of Lake Winnipeg between Winnipeg Beach and Riverton. Interest has particularly centered on spruce and jack pine budworm activity between Lake Winnipeg and the Manitoba-Ontario boundary. Nearly everywhere the two forms occurred together with feeding 
on jack pine noticeably heavier than on spruce. South of the Berens River a medium infestation of the jack pine budworm was recorded at Aikens Lake near the border. In southeastern Manitoba infestations in the Whiteshell and Sandilands Forest Reserves and contiguous regions continued at medium and heavy intensities respectively.

Larch Sawfly. The larch sawfly continues to be the most important forest pest of the region and was generally distributed in Manitoba and Saskatchewan, but has not been reported from Alberta. In Manitoba a general increase in severity of infestation was recorded. In Saskatchewan severe defoliation was encountered in scattered stands along the eastern border, but further west, infestations were generally light.

The aspen tortrix was active on trembling aspen in the Duck Mountain regions of Manitoba and Saskatchewan. American poplar leaf beetle damage was also reported from this area as well as from other areas in Manitoba, Saskatchewan, and Alberta. In the eastern region of Saskatchewan the western willow beetle caused widespread defoliation. Unusual infestations of the birch sawfly occurred in southeastern Manitoba.

British Columbia Interior:

False Hemlock Looper. An outbreak of this species on Douglas fir over an area of 40 square miles has been recorded in the Windemere District. Since the Christmas tree industry of the Kootenay region is centered in this area, as well as a number of tourist resorts, the outbreak is of importance.

Lodgepole Pine Needle-miner. The population of this species remained at a high level in Banff National Park.

Mountain Pine Beetle. The population of this species in Banff National Park has declined. A decline of the Leanchoil area was also recorded. In both cases the decline is attributed to control operations carried out in previous years.

Western Hemlock Looper. The infestation on the Big Bend of the Colum. bia River has subsided completely.

Larch Sawfly. The lowest population level since 1933 when the species was first reported in British Columbia was recorded in 1947.

Douglas Fir Tussock Moth. The peak of current infestations in the Kam. loops and Okanagan areas is believed to have been reached during 1947.

British Columbia Coast:

Western Hemlock Looper. On Vancouver Island the hemlock looper populations subsided in areas of extreme devastation in previous years, and a general decline was noted in the coastal forests. However, some localized infestations persisted in 1947, chiefly at Gordon River, the Upper Nitinat Valley and Poett Nook on the Alberni Canal and south of Jarvis Inlet on the mainland. Timber mortality resulting from the severe 1946 defoliation has become very great.

Hemlock Sawfly. There was a general increase in the population status of this sawfly on Vancouver Jsland, particularly on Nereutsos Arm of Quatsino Sound, as well as on the Queen Charlotte Islands and on the mainland, especially south of Jarvis Inlet. Although the populations had 
noticeably increased, no serious defoliation was yet apparent.

Alder Sawfly. For the third year total defoliation of alder occurred in some parts of the Queen Charlotte Islands.

Oak Looper. An outbreak of this species has coincided with the outbreak of the hemlock looper, and it appeared in increasing numbers over the southern part of Vancouver Island during 1947. Total defoliation of oak occurred for the second year, but no mortality has developed. Douglas fir in association with oak was also stripped. Indications point to continued abundance in 1948.

Spruce Gall Aphid. This insect is a general pest on Douglas fir being particularly severe on two-year-old seedlings in plantations. However, it also attacks trees of sapling size though comparatively little injury is caused to the larger trees. The gall-forming alternate generation occurs on Sitka spruce wherever this tree occurs and the gall injury combined with injury caused by the Sitka spruce weevil constitutes a serious threat to spruce, again chiefly in plantations.

Tent Caterpillars. These insects caused severe defoliation especially at Victoria, Duncan, Powell River, Texada Island and north Vancouver. The western tent caterpillar was particularly numerous although the forest tent caterpillar was also present. Parasitism was very low in the infestations at some Vancouver Island points, but at Powell River on the mainland it ran over 75 per cent.

Ambrosia Beetles. These insects persist as a perennial problem in logging areas, but have recently become of importance, attacking the trees killed by the hemlock looper in the southwest portion of Vancouver Island.

\section{Suggestions and Comments Regarding Research and Control}

Forest entomology has made great strides in recent years. Funds for research have been greatly increased, new laboratories and equipment and increases in staff have been secured. Co-operation of forest insect research units with industry, with similar units in the United States, and with joint entomological and pathological investigations are all signs of progress. How. ever, we should not be lulled by these recent advances into a false impression that our forest insect research organization is complete as to staff, facilities or programme.

Many of the recent advances have come as a direct or indirect result of the current spruce budworm outbreaks. We must not lose sight of the fact that the protection of all Canadian forests against all forest insects is the objective of forest insect services as well as the forest protective services and the forest industries which are equally concerned; and that this objective necessarily requires co-operative research with forest services, with industry and with forest pathologists for the ultimate solution of many of the most pressing problems. It is particularly important to realize that the results of forest insect investigations in order to be expressed in actual forest protection involve the closest co-operation with the organizations administering and util. izing the forest resources. An important element in the realization of this objective is the resolution of the problems in economic terms. Some studies of 
the costs of forest management directed to minimizing the spruce budworm hazard in the forest have been conducted in the northeastern States. The Green River project and similar management experiments to be conducted elsewhere should all yield results which can be expressed in economic terms. How ever, probably not all of the elements which enter into economic calculations can be forecast or measured with any certainty, and in view of the tremendous losses caused by forest insects throughout Canada in recent years with the attendant dislocation and modification of plans of exploitation, it is perhaps more pertinent to suggest that we cannot afford not to implement management plans for the protection of the forests against forest insects just as soon as sound recommendations can be made, than to debate for many years to come whether such plans are economically feasible in the light of prevailing economic conditions.

The shortage of trained personnel is still keenly felt and there must be many more trained forest entomologists before a complete programme can be developed. Existing scholarships should be continued and possibly increased, but there can be no gain from this step unless facilities for under. graduate, and particularly, graduate instruction are expanded. In the past eight years Chairs of Forest Entomology have been established at the University of New Brunswick, the University of Toronto and most recently at the University of British Columbia. These are steps in the right direction, but equipment and facilities must be increased so that students of forest entomology may be adequately trained.

The solution of long outstanding forest insect problems is, therefore, de. pendent not only on the continued development of the facilities for laboratory and field research in the various parts of Canada, but also upon the maintenance and increase in the development of co-operative projects involving the forest services, the industry and the forest entomologists and pathologists, and, of course, upon the ability of the undergraduate and graduate schools of instruction and forest entomology to turn out qualified investigators in sufficient numbers. The necessity of such co-operative action may be illustrated by the fact that only very few major forest insect problems in Canada are now receiving that degree of co-operative intensive investigation to justify the belief that an effective solution will be found in the foreseeable future, and even in such cases the solution will undoubtedly rest in part with those concerned with administration and utilization of the forests. Persistent efforts must, therefore, be maintained by the Canadian Society of Forest Eng. ineers to ensure that training facilities are adequate, that research programmes are kept up to date and extended wherever necessary, and that a high degree of co-operative action is brought to bear upon the most urgent problems. Suggestions and criticisms from the membership of the Society bearing upon the objectives just referred to would be very much appreciated by this Committee, the members of which are Messrs. C. E. Atwood, A. H. Burk, H. J. Hodgins, L. S. Hawbolt, C. C. Heimburger, C. B. Gill, R. R. Lejeune, H. A. Richmond, and C. R. Silversides

M. L. Prebble, Chairman.

A. S. WeSt, Secretary. 
FOREST FIRE

Members of the Committee are:

H. W. Beall (Chairman), Chief, Forest Protection Division, Dominion Forest Service, Ottawa, Ont.

G. W. I. Creighton, Provincial Forester, Halifax, N.S.

G. L. Miller, Chief Forester, New Brunswick Forest Service, Fredericton, N.B.

G.H. Bermier, Asst. Chief, Forest Protection Service, Quebec, P.Q.

R. Bellefeuille, Chief, Economics Division, Forest Service,Quebec, P.Q.

$R$. N. Johnston, Chief, Division of Research, Department of Lands and Forests, Toronto, Ont.

P. McEwen, Regional Forester, Forest Ranger School, Dorset, Ont.

S. W. Schortinghuis, Chief of Fire Protection, Manitoba Forest Service, Winnipeg, Man.

E. J. Marshall, Director of Forests, Prince Albert, Sask.

T. F. Blefgen, Director of Forestry, Edmonton, Alta.

J. R. Johnston, (Secretary), Fire Control Officer, British Columbia Forest Service, Victoria, B.C.

Fire Danger Research and Fire Control Planning

Dominion Forest Service

An intensive fire-hazard research program was conducted at the Kananaskis Forest Experiment Station, along lines similar to those employed in the previous year. The main projects investigated were the relationship between weather, fuel moisture content, susceptibility of fuels to ignition, and fire behaviour; development of apparatus for the measurement of moisture content in deep and heavy fuels; characteristics of inversions and their effect on fire danger; and the influence of seasonal changes in vegetation on the fire hazard. Although the past two fire seasons have been unfavourable to these studies, sufficient data have now been obtained for a preliminary analysis of the problems involved. An analysis of inversions and their effects is now in progress. Pending the results of these investigations, further field work at Kananaskis will be on a somewhat reduced scale.

At the Petawawa Forest Experiment Station, firedanger research was limited to certain fuel moisture studies, and to the investigation of chemicals which might serve as simple indicators of forest inflammability.

Data were abstracted, at the Acadia Forest Experiment Station, from reports supplied by the New Brunswick Forest Service on nearly two thousand forest fires which have occurred in New Brunswick during the past nine years. It is believed that analysis of these records will lead to further im. provements in the Wright system of fire-danger rating used in that province. Information of value to forest protection officers will also be obtained regarding the occurrence, distribution, and other characateristics of fires in each forest district. 
At the request of the Newfoundland Forest Protection Association, a brief analysis was made of fire oxcurrence in relation to the danger index which is computed by the Wright System at forest weather stations in Newfoundland. The results indicated that, with some modification of the tables for eastern Canada, a reliable indication of fire-danger conditions is pro vided.

From a study of many hundreds of test-fire records, tables were prepared by means of which the element of personal judgment may be greatly reduced when assessing the fire hazard by direct observation of small, experimental fires.

Studies conducted for some years past with various hygroscopic chemicals, in an effort to develop a simple indicator of forest fire hazard, now show some prospect of success. Sulphuric acid is used in a specially shaped container which permits rapid volumetric measurements; this container was designed by Dr. Hurst of the National Research Council. Some chemicals and containers have been eliminated as a result of recent analyses, and further investigation will be made with the more promising types. Studies of inorganic hygroscopic solids, intended for the same purpose, will also be continued.

An investigation was made of the loss of water by evaporation from rain-gauges, when the latter are used for climatic studies at a distance from inhabited localities and are read at infrequent intervals. Readings of the standard Canadian meteorlogical pattern rain-gauge were found to be appreciably affected by evaporation loss if observations were made more than a week apart. The introduction of a small quantity of kerosene the equivalent of about two one-hundredths of an inch of rain) in the receptacle, however, provided a film over the surface of water subsequently collected, which effectively prevented measurable evaporation during a seven-week period.

A forest-fire control plan has been prepared for the Petawawa Forest Experiment Station. This Station now contains more than 500 sample plots, whose value from the standpoint of silvicultural research warrants much more intensive fire protection than commercial timber and other values alone would justify. The plan sets forth the standards of fire control which are considered necessary in the light of the past 18 years' fire experience, and specifies the organization, equipment, fire-control facilities and state of preparedness designed to meet these objectives. The fire atlas which forms a part of the plan includes maps showing the location and causes of past fires, areas visible from lookouts, fuel types, travel routes and travel-time zones, and fire-fighting facilities. This fre control plan is to be published in bulletin form. Work in fire-control planning has also been started at the Acadia Forest Experiment Station.

Progress has been made in a study to determine standards of adequate forest-fire protection for the various forest regions of Canada, a preliminary outline of which has been prepared. Valuable assistance in this project has been received from a number of provincial forest protection services. 


\section{British Columbia}

Fire weather research was extended during the past summer to the Southern Interior portion of the province. An attempt was made to set up a fire-weather recording system in the Interior, similar to that developed last year for the Vancouver Forest District. The results proved even more satisfactory than was hoped for, and it is felt that if instrumetns are available for next summer a reasonably complete organization can be set up.

Manitoba

In 1947 ten fire-hazard recording stations were set up in the southem portion of the province. Results during the greater part of the fire season were considered to be very good, but some modification of the present danger index tables, especially in the spring hazard period, will likely be necessary. It is planned to establish ten more forest weather stations in the northern and eastern ranger districts next year. Radio reports from such stations should aid in planning detection flights.

Ontario

Between 50 and 60 forest weather stations were operated in the province during the past season. Several systems of fire-danger rating were used for comparative purposes. The state of preparedness to be maintained according to the prevailing degree of fire danger has been specified in some districts.

An analysis was made of fire occurrence in the Fort William Area in relation to the Lands and Forests Hazard Meter and to a regression equa. tion calculated in the Port Arthur District. Close agreement between the two methods of fire-hazard measurement was found.

Quebec

Research was carried out on climatic conditions in different forest stands, and also on the relation between the inflammability index and actual fire occurrence. These studies, which are designed to assist in applying the index to fire prevention and suppression, are still in progress.

\section{Dominion Forest Service}

\section{Education and Prevention}

The first year of a resumed study of the effectiveness of certain chem. icals for retarding the growth of vegetation on fire-guards and roadsides was completed. Although it is yet too early to draw definite conclusions, results on the whole have been disappointing. To date, the most effective treatments appear to be a 10 per cent solution of sodium chlorate, and fuel oil of specific gravity $26-32$ deg., both applied at the rate of 1 gal. per 100 sq. $\mathrm{ft}$. Living vegetation at the end of the first year was roughly 50 per cent of that on untreated plots, in both cases. Definitely poorer results were obtained with 5 per cent sodium chlorate and with $20-26 \mathrm{deg}$. fuel oil. The effect of adding 5 per cent calcium chloride to the sodium chlorate solution, as regards toxic properties, has not as yet been conclusively determined. The calcium chloride did, however, reduce inflammability by 2 to 3 units on the Wright scale, compared with untreated plots, in the spring following a late autumn treatment, where as all other treatments increased inflammability by 3 to 4 units. 
Quebec

A Forest Protection School, which provides eight weeks' specialized training for graduates of the Forest Ranger School, was opened at Duchesnay in the fall of 1947 . The course includes 300 one-hour lessons, divided equally between lectures and field work. The subjects are as follows:

Lectures:

1. Legislation

2. Job instructor's training

3. Meteorology

4. Entomology

5. Forest pyrology

6. Prevention

7. Organization

8. Pre-suppression activities

9. Fire-fighting

10. Administration

Practical Work:

1. Erection of a wooden tower

2. Erection of a steel tower

3. Construction and operation of telephone lines

4. Installation and operation of a radio network

5. Use of fire-fighting equipment, especially mechanical equipment

6. Methods of fire-fighting, organization of crews, etc.

7. Fire reports, drawings, surveys, etc.

Each graduate receives a certificate qualifying him as a licensed inspector. The eight graduates of the first class are all employees of the forest protection organizations of the province.

\section{Dominion Forest Service}

\section{Detection}

Tests were made to determine the usefulness of Army No. 24 smoke generators as aids to forest-fire detection. A supply of these generators was purchased by a number of forest protection services last year. The generators should be of value for checking the alertness, bearing accuracy and visible. area coverage of lookouts, as well as providing "mock" fires in connection with fire drills. The smoke is easily visible to the naked eye at a distance of 15 miles, and should be reported within 2 or 3 minutes after ignition under favourable conditions of visibility. Because of the speed with which a large volume of smoke is produced, the generators are not well adapted for checking the ability of lookouts to pick up "small" smokes. They are easy and safe to use provided that reasonable caution is exercised. They may, however, blow out sparks, which are capable of starting fires, to a distance of some yards, and should therefore not be used close to inflammable material.

A comparison was made between binoculars equipped with "coated" lenses, and a similar pair with plain lenses. The coating of each air-andglass surface with the proper thickness of magnesium fluoride reduces re flections in the optical system, and thus increases the amount of light transmitted to the eye. It was found that under poor light conditions (e.g., after 
sunset, in very dull weather, or with visibility reduced by obscurity of the atmosphere) coated lenses were a definite aid to lookouts in detecting smokes. On bright days with good visibility, while the overall brightness of the image was increased with coated lenses, there was no apparent gain in ability to pick up smoke. The cost of coating a pair of binoculars not originally supplied with this treatment is about $\$ 25$.

National Parks

Preliminary tests were made at Banff with Army No. 5 smoke genera. tors, which are smaller and lighter than the No. 24 and thus more convenient to carry. Two or more of these generators may be required to produce a satisfactory smoke under some conditions. It is expected that a more detailed report will be available next year.

British Columbia

Two visibility mapping crews were employed in the Okanagan District of the Southern Interior, gathering information necessary to establish a primary lookout network in that area.

Lookout photography was continued, with 8 new lookouts photographed and 5 previously photographed lookouts re photographed. As improvements to the standard, gridded panoramic views, a celluloid roamer carrying the grid for the central portion of the photograph is being tried out, as well as a new loose-leaf method of binding the photographs.

The use of aircraft in the Interior to supplement lookout coverage and supply detection patrols for remote areas was continued last summer, four aircraft being contracted for this purpose.

Manitoba

Nine steel and two timber towers were constructed in 1947, and two new forest ranger districts were established.

Ontario

An intensive program of visible area mapping from lookout towers is in progress, to determine the efficiency of the present lookout system and to aid in planning additional coverage.

New Brunswick

Air patrols were used for the first time in 1947. In spite of difficulties in obtaining a suitable radio frequency, which it is expected will be remedied next year, these patrols proved very beneficial on many occasions.

\section{COMMUNICATION}

A conference was held in Ottawa, to which representatives of all governmental forest protection services in Canada were invited, for the purpose of discussing with signals officers of the Department of National Defence the possibility of co-operation in matters relating to forest radio equipment. It appeared that military apparatus at present available was not well suited to forestry requirements in most regions, although possibilities for useful co-operation in the future were foreseen.

A progressive step was taken by the forestry representatives at the conference, in the drafting of specifications for a light-weight portable transmitter-receiver of the "handy-talkie" type, which it was felt would have widespread application for short-range forest communication purposes. These 
specifications were referred to the protection services concerned, and were in general very favourably received. There would appear to be an immediate requirement for at least 200 of such sets. The specifications have also been approved by the Radio Division, Department of Transport.

No apparatus corresponding to these specifications is at present on the market. It is believed that the radio industry would be in a better position to produce such equipment at moderate cost if the design and developmental work were undertaken by some military or governmental agency, such as the Canadian Signals Research and Development Establishment. This possibility is now being taken up with the Department of National Defence.

\section{British Columbia}

During 1947, with all types of radio supplies more abundant and increased funds available, considerable progress was made in Forest Service radio development. Efforts have been directed towards the improvement of reception by the reduction of noise level and by an attempt to obtain a more suitable long-distance frequency.

A multi-channel remote control receiver unit, installed successfully at Nelson in 1946, is now used in Vancouver, Prince George and Victoria, the overall effect giving vastly improved reception. During the summer, sites were chosen for five more remote units.

Forty additional Type SPF and PAC sets were purchased during the year. Two new improved type launch units were also purchased; one, of 65 watts, gave the "Forest Surveyor" excellent communication throughout the summer, replacing the old Type L 50-watt unit. At present still at the factory but nearly ready for installation, is a new unit of 100 watts for the M.V. "Syrene."

With shortage of frequencies a major problem, it is hoped to obtain a separate frequency for each forest district and a long-range frequency which will put all districts in constant touch with Victoria.

Actual communication activities as measured by the number of mes. sages (exclusive of conversations and weather reports) handled by headquar. ters station at Victoria have increased considerably in the past two years.

Messages handled, $1945 \ldots \ldots \ldots \ldots .1,330$

Messages handled, $1946 \ldots \ldots \ldots \ldots . .2,528$

Messages handled, 1947 (up to Nov. 20) 3,360

Nova Scotia

Electric megaphones have been installed in aircraft used by the Forest Service, permitting the pilot's voice to be heard very clearly on the ground from an altitude of 1,500 feet. This arrangement proved useful for contacting rangers directly from the air, thus avoiding delays in relaying messages. It also enabled a close check to be kept on danger spots along a fire line. Another important use of the loud speaker was for warning campers, brushburners, people burning slab piles at sawmills, etc. These aerial admonitions were found to have a very salutary effect. It is understood that the apparatus costs about $\$ 150$. 
British Columbia

\section{TRANSPORT}

Owing to a comparatively light fire season, there was very little opportunity for new developments in dropping supplies from aircraft. A limited number of fires were, however serviced by this method.

Saskatchewan

The Saskatchewan Forest Service is the first-and to date the onlyfire-control organization in Canada to train and employ parachutists or "smoke jumpers" for forest fire suppression. A smoke jumpers' school was established at Prince Albert in the early summer of 1947, at which eight men were given an intenive course of training for $11 / 2$ months. Plans have been made to train an equal number next year.

Before acceptance, trainees were required to pass a strict mental examination, be between the ages of 22 and 32, weigh not more than $175 \mathrm{lbs}$. and be "temperamentally stable." They were also chosen for their forestry experience and fire-fighting ability. After passing these requirements, each man was insured for $\$ 5,000$ by the Saskatchewan Government Insurance Office. Students were instructed in first aid, forest fire control, 'chute packing and the theory of parachute jumping, as well as gymnastics and practical exercises. Each man was required to make seven jumps before being graduated.

Although the smoke-jumping technique follows fairly closely the method developed by the United States Forest Service in Montana, a number of important adaptations to northern conditions had to be made-notably the safe discharge of parachutists from pontoon-equipped planes. This was accomplished by means of a "coal scuttle" chute, down which the jumper slides clear of the floats.

Actual jumping operations are directed by the "jumpmaster," who first drops a drift 'chute to assess wind conditions. While the aircraft circles the target area, each jumper slides down the chute in turn on a signal from the jumpmaster. Parachutes are opened by static line, but an additional chest pack, which may be opened by a manual rip-cord, is carried for emergency use.

Each jumper wears a heavily padded suit and crash helmet. He carries a compass, sheath knife, first-aid kit, two signal streamers to let the pilot know he has landed safely, a 90 - $\mathrm{ft}$. let-down rope to be used in getting out of trees, and a $12-\mathrm{ft}$. release rope for escaping from the harness. A two-man fire pack containing equipment is dropped separately. A 76-1b. pack contains a cross-cut saw, map case, two shovels, a bed-roll for two men, two water bags, a protractor set, pruning saw, 15 -meal ration kit, two Pulaski tools, an axe, two pack sacks, two mess tins, two bottles of mosquito oil, salt tablets, two headlights, and a $28 \mathrm{lb}$. radio set.

The tactical employment of smoke jumpers is largely confined to small fires in areas otherwise difficult of access. By thus drastically reducing travel time, many such fires may either be controlled in their incipient stages, or checked until reinforcements arrive.

(More detailed information on this interesting development appears in "Aircraft and Airport" for August, 1947.) 


\section{Manitoba}

The Department of Public Works spent $\$ 200,000$ in 1947 on tourist roads in forested areas. These will bo of great importance from the stand. point of access to fires, as well as for timber extraction.

The Provincial Air Service now has six modern float-equipped ma. chines. Two of thelse are "Huskies" which have a door in the tail of the fuselage, permitting the easy loading of canoes and dropping of supplies by parachute. Experiments in the latter connection were made with parachutes supplied by the Alberta Forest Service.

A fully-equipped sub-base for aircraft has been established at Grace Lake, near The Pas.

\section{Ontario}

The Department of Lands and Forests co-operated with the manufactur. ers in the production of the "Beaver"-a semi-transport aircraft incorporating features particularly suited to the requirements of the Provincial Air Service.

An intensive study was made of the possibilities of the helicopter, with particular reference to its application in fire-control operations. The following is an abstract of a report on trials made in the Port Arthur Distict. This report deals with the use of a Bell Helicopter during the period September 4 to 26, 1947, when it was used for several purposes, the principal one being transport of men and equipment for fire suppression.

The main characteristics of the machine are as follows: Bell Aircraft Co., manufacturer; agricultural model with windshield and open seats; two passengers; fitted with flexible pontoons, amphibious; flying speed 65 to 75 m.p.h.; gasoline capacity 26 gallons; range 150 miles; Franklin air-cooled 178 h.p. engine; pay load rated at $350 \mathrm{lbs}$., but machine carries $400 \mathrm{lbs}$. safely when good take-off space is available. Flying costs, which include overhead and maintenance, are about $\$ 100.00$ an hour. When the helicopter is used away from its main base, it is essential that a jeep trailer carrying service equipment and spare parts be taken to the temporary base.

A base can be established within a radius of 100 miles in half a day, the most important point in so doing being the supply of the necessary quantity of 80 octane, clear, unleaded gasoline. Under ideal conditions, this helicopter can efficiently service, from one base, an area of 100 miles radius, or approximately 31,000 square miles.

The machine was very airworthy, but check-ups are required at every 25 hours' flying, with a teardown every 100 hours. It was steady in flight, but an up-and-down jiggle made note-taking difficult. Bumps were rarely felt. It has an advantage over the conventional plane when taking off or landing in strong winds. Because of the danger of being struck by the tail rotor when the helicopter is on the ground, or by the main rotor when it is approaching the shore of a lake or pond, a safety routine for personnel should be established.

With moderate loads the helicopter can take off vertically. It can land on an area somewhat larger than itself, but if the landing place is in standing timber, it should have an opening more than fifty feet in diameter. 
Pot-holes make good landing places, and the machine may settle with one pontoon in the water and the other on land.

Auto rotation (engine shut off) landings are made readily and under perfect control. The helicopter is manoeuverable on water while the rotoris are turning, but if there is no landing place on shore, it must be paddled in and out, a paddler being required on each pontoon.

From experience in using the helicopter for fire suppression, it seems reasonable to assume that an average pay load of $300 \mathrm{lbs}$. could be carried, and an average elapsed time of one hour per 10 mile round shuttle. Longer shuttles should not take a proportionately longer time, since the loading and unloading periods would be less in relation to flying time.

The helicopter pilot believed that, of the country he saw in the Port Arthur District, a landing could be made within two miles of almost any point. Many landing places could be provided by a little axe-work around natural openings in the tree cover. While in this District the helicopter was used to service a fire, to patrol for fire, to test proposed tower sites, and to test availability of landing sites in bush country.

The helicopter did not hover steadily when testing tower sites. It glided and turned, about 50 feet above the tree tops, making precise observations and lengthy considerations impossible. However, the machine was useful in weeding out bad sites and in picking out hills with very good visibilty. The ability of the helicopter to rise vertically over a proposed site is a great advantage in investigating blind areas.

The helicopter can do its own type of flying in practically all situations where a plane can fly, and in addition in a great number of situations where a plane cannot fly. However, it is not economical to use the helicopter on fires which can be serviced by a light plane or by other conventional methods. It should prove to be very useful in getting to so-called inaccessible dry areas.

New Brunswick

An experiment in the use of light "Fleet-Canuck" aircraft for forest-fire protection purposes was inaugurated by the New Brunswick Forest Service. The contract called for two aircraft (one of which was to be an amphibian) with another plane as a spare. Seven hundred out of 1,000 contracted flying hours were used up to the end of the fire season.

The aircraft proved extremely useful in obtaining information during fire-suppression operations, as well as for patrols. The planes were also employed for sketching and photographing fires, although the light aircraft were of little use for this purpose during high winds.

Nova Scotia

A "Seabee" was used during the past year to fly essential equipment and supplies to fires, and proved very satisfactory. As the province is surrounded by water and has a large number of lakes, very few fires occur where a plane of this type cannot be used.

For moving heavy mechanical fire-fighting equipment, a White truck and trailer have been purchased, the unit being $37 \mathrm{ft}$. in length. Tractors can easily be driven on and off by means of a ramp. 


\section{Fire-Fighting EQUipment and Methods}

\section{National Research Council}

Tests were made on a portable forestry pumping unit equipped with rubber gears which were designed to resist abrasion when pumping muddy water. A report on these tests has been prepared by the Research Council. Dominion Forest Service

Forest-Fire Research Note No. 13, "Effect of Altitude, Length of Hose Line and Head on Performance of Forest-Fire Pumping Units," was issued in 1947. This shows the discharge rate, pressure at pump and nozzle, and length of stream to be expected under various operating conditions from portable forestry pumps commonly used in Canada. A quick and efficient method of testing pump performance in the field is also described.

Additional tests were made on a Panama fan-belt drive pump, designed for mounting under the engine hood of a car or truck and powered by the latter's motor. Discharge rates of 20 g.p.m. and 10 g.p.m. were obtained at pressures of 50 and $100 \mathrm{lb}$. per sq.in., respectively. This gear pump, which is fitted with a relief valve, is intended for use in small, tank-carrying vehicles, and may also be arranged to pump from outside water supplies.

A light tanker unit, consisting of a $4 \times 43 / 4$-ton truck with 100 -gal. tank, live hose reel, pump, fog and straight-stream nozzles and hand tools, is being made for use at the Petawawa Forest Experiment Station.

A hose vulcanizing press, designed some years ago by J. G. Wright, was made recently by the Penitentiaries Branch of the Department of Justice at a cost of about $\$ 85$. The press accommodates linen or rubber-lined hose of $1 \frac{1}{2}, 2$ and $2 \frac{1}{2}$ inch sizes, and can be used for both patching and splicing. The splices are shaped to lie flat when not under pressure, and thus do not interfere appreciably with rolling or folding. Repairs made in 1941 with an earlier model of the device gave excellent service; the new press is now being tried out at Ptawawa.

Tests were made with a Western fog-stream-shutoff nozzle, having three interchangeable fog tips, and three straight tips of $1 / 8,3 / 16$ and $1 / 4$ inch diameter. Discharge from the fog tips varied between 2 g.p.m. for the smallest tip at $50 \mathrm{lb}$. per sq.in. pressure, to 7 g.p.m. for the largest tip at 180 lb. per sq.in. Good fog was produced at $100 \mathrm{lb}$. pressure, and partial fog at $50 \mathrm{lb}$. The effective reach of the fog was between 18 and 25 feet. The fog nozzle discharging 5 g.p.m., and a straight-stream nozzle delivering 30 g.p.m., were used experimentally for controlling a fire in a disused, oilsoaked shack. Apart from discomfort experienced when approaching within 20 feet of the flames, the extinguishing properties of the fog compared quite favorably with those of the straight stream, in spite of the disparity in the amount of water used. It would appear that the fog nozzle is well adapted for use when the water supply is limited, as on tank trucks. No opportunity occurred to test, on an actual forest fire, either this nozzle or a Grinell "Flamebuster" with forestry applicator, which was acquired later in the season. 
During the spring hazard period experiments were made at Petawawa to determine the effectiveness of a wetting agent, and of the fire retardant mono-ammonium phosphate, for controlling surface fires when applied by means of back-pack tanks and hand pumps. One series of tests was made in "flash" heath fuels, the other in slash piled in windrows. The wetting agent was used in a 1 per cent, and the mono-ammonium phosphate in a 20 per cent, solution.

It was found that two tanks of mono-ammonium phosphate were equivalent to three tanks of plain water for controlling heath fires; the wetting agent showed no advantage over plain water for this purpose. The amount of both chemicals required to extinguish slash fires was 80 per cent of that of plain water. No opportunity occurred for testing the chemicals on deepburning fires in litter, humus or moss, where it would be expected that the penetrating properties of the wetting agent would show up to best advantage.

Galvanized tanks were stored with both the above chemicals throughout the fire season. At the end of the season the tank containing the wetting agent was somewhat corroded, but brass and copper fittings were undamaged. The mono-ammonium phosphate caused considerable corrosion, especially on the brass and copper. It would thus appear that these chemicals should not be stored in back-pack tanks for any length of time. This is no serious disadvantage in the case of the wetting agent, which goes into solution very quickly and easily, but the mono-ammonium phosphate is more troublesome to prepare.

(Further comments on the use of wetting agents are given in the reports from Ontario and Quebec below.)

\section{British Columbia}

At the request of some of the districts, fire suppression crews last summer were made up of 12 men instead of the usual 8 . This was done so that half the crew could be used on improvement work during periods of moderate hazard and still leave enough men on standby to form an effective fire-fighting unit. Fourteen crews were employed, distributed throughout the high risk areas of the province.

Manitoba

It was hoped to equip two Fordson tractors with Ferguson hydraulic systems, but shortages of this equipment last winter and the need for these tractors during the summer made the postponement of modification necessary. There was no occasion to use the Fordsons on fire suppression in 1947. Due to the breakdown of two crawler type tractors during the planting season, the Fordsons were used for ploughing in connection with spring planting. All the planting of 79,000 trees in the Sandilands Forest Reserve was done with this type of tractor, and some ploughing was done in connection with planting and fire-guarding in the Spruce Woods Reserve. Sixteen-inch walking ploughs were used. It was found that ploughing with the Fordson was satisfactory in sand soils where duff and ground cedar were negligible. It is believed that a Ford-Ferguson unit with 16.in. breaker plough will be the most useful fire-fighting equipment for the light soils where it is intended to use them, but not for heavier soils. 
Ontario

Comparative tests of plain water, and water to which a wetting agent had been added, were made using as nearly identical stacks as possible, and fring them under similar condition of wind, surface temperature and relative humidity. So far as could be seen, there was very little difference between the extinguishing effect of treated and untreated water on these stacks, which might be taken to indicate conditions existing in a hot slash fre.

A few unsatisfactory tests were made of the effect of the wetting agent on ground fires. There was some indication that the treated water had more extinguishing power for fires of this type. It also appeared that to be effective a higher concentration of wetting agent than that recommended by the manufacturers should be used. It is hoped to complete tests of wetting agents on rotten wood and humus during the winter.

In order to attempt to make practical use of the recommendations contained in Research Report No. 11, "Fungicides for Fire Hose," experiments were conducted in 1947 on treating unlined linen forest fre hose with copper napthenate to resist mildew. The findings of these experiments may be summarized as follows:

(a) The highest copper content was obtained when the hose was scrubbed before treatment and the fungicide solution was heated to $140 \mathrm{deg}$. F.

(b) There appears to be little advantage in wringing the hose after treatment. However, wringing may cause the fungicide to be more evenly distributed throughout the fabric and may also speed up the drying time.

(c) Pumping the solution through the hose does not appear to improve the process.

(d) Treating the hose without previous preparation, although resulting in the lowest copper content, compares quite favourably with sam. ples that were scrubbed and washed before being dipped in the fungicide.

(e) The reduction in copper content due to leaching when water is pumped through the hose in actual use does not present a serious problem.

(f) Consideration should be given to raising the mininum copper content from 0.4 per cent to, say, 0.45 per cent.

The good resistance to leaching shown by the tests, and the satisfactory resistance to mildew shown by Research Report No. 11, would indicate that this method of preserving fre hose from rot is a satisfactory one. However, there is the disadvantage that when the copper content is made sufficiently great to give the desired protection, the hose becomes rather stiff to handle. No further attempts to devise suitable apparatus for treating hose in bulk will be made unil new fungicides, claimed to have improved characteristics, have been investigated.

Two innovations are reported from the North Bay District:

(a) In an effort to reduce wear and tear caused by vibration in pumping units, the pumps are suspended on discarded valve springs placed at the four corners between the base of the pump proper and the wooden carrying frame. 
(b) To eliminate the annoyance of hand pumps being knocked from the clips on top of metal back-pack tanks when carried through the bush, the pumps are hung at the sides of the cans by means of wire hooks and rings.

The following comments on the use of a bulldozer for fire-line construction in a cut-over area are summarized from a report on a fire in the Port Arthur District:

(a) A large bulldozer, heavily enough powered to clear its way through stumps, proved very effective. A smaller unit which could not push the stumps over, yet was too big to manoeuvre between them, was not satisfactory. Possibly a very small and relatively portable tractor. bulldozer combination, such as the "Beetle," would be useful in such cases.

(b) Several days after the fire was declared out, embers were found smouldering under earth turned over by the bulldozer. This experience indicates that the bulldozer should be worked at a distance from the fire edge, and should not be used to smother burning ma. terial.

(c) Consolidation of a bulldozed fire line is just as important as one Quebec made with hand tools or pumps.

Experiments in fire suppression were made with two types of wetting agent, both of which appeared to be useful for fighting fires in duff and moss. In spite of the fact that corrosion of equipment took place, it is believed that the advantages of these products justify their use.

New Brunswick

An investigation of various phases of forest-fire suppression in the province was made by Dr. J. M. Gibson. A number of Dr. Gibson's recommendations have already been put into effect.

A large quantity of motor vehicles, camp equipment and miscellaneous supplies was purchased from War Assets Corporation during the year. As many of these items were difficult to secure elsewhere and were obtained at a very reasonable cost, advantage was taken of the opportunity to build up even higher stocks than present demands might require. A number of new buildings and fire-fighting equipment were also acquired.

Fourteen R.C.A.F. re-fuelling tankers, varying in capacity from 500 to 1,000 gallons, were put into service for forest-fire suppression work, and with some modification have proved most valuable. The hose reels, meters, etc., were removed from the rear compartment, and a Wajax pump installed, which can pump either from the tank or an outside supply. To fill the tank a Homolite 15,000 gal. per hour pump is used, the forestry pump proving too slow for this purpose. The boxes on the sides of the tanker are used for carrying hose, oil, etc., but as these compartments are rather low they are subject to damage on rough roads. It is intended to replace them with racks on the cat-walks, which will also carry water tanks and hand tools sufficient to make a self-contained unit for brush burning and fire suppression. The 1,000-gallon tanker, which is too low and heavy to be used off highway roads, 
will be especially valuable for brush-burning operations adjacent to settlements. For the present it is planned to allocate two tankers to each forest district.

Considerable publicity was given to an attempt by the Bathurst Air Services Limited to make rain with dry ice. The experiments, however, were inconclusive, and there is a good deal of doubt as to whether this technique can profitably be included in the forest-fire protection program.

Nova Scotia

Mechanical fire-fighting equipment proved its worth on a number of fires. It is difficult to determine the full worth of such machines as bulldozers, since this type of equipment cannot be used efficiently on fast. spreading fires. When a fire is not advancing rapidly, however, the work of the bulldozer saves many acres of forest land. On all fires that it has been possible to surround with a bulldozed line, no advance has resulted, and in cases where it has not been possible to get around the fire, certain sections have been held by their use, allowing a greater concentration of man-power in other areas.

Alberta

General

One of the most favourable fire seasons on record was experienced in this province, and there were no important developments in forest-fire research.

\section{Yukon and Northwest Territories}

The organization of forest-fire protection services in the Yukon and Northwest Territories was begun in 1946, and is still in progress. For the present, attention is being largely concentrated on the Mackenzie River where patrol boats are used, the vicinity of Yellowknife where there is considerable prospecting activity, and the Alaska highway. It is hoped that a more complete report on fire protection activities in these Territories will be available next year.

\section{Plans for Forest-Fire Research in 1948}

In accordance with recent practice, the Committee has endeavoured to list the main forest-fire research projects proposed by each agency in Canada for the coming year. It is hoped that by this means those interested in particular phases of fire research may be able to see what has been planned elsewhere, and may be able to communicate with other organizations where it is felt that mutual benefit may result and duplication of effort may be avoided.

Fire Danger Research and Fire Control Plans

1. Continued studies relating to fire-control planning (Ontario Dept. of Lands and Forests; Quebec Forest Protection Service; Dominion Forest Service).

2. Investigation of the application of the bolometer for test-fire observation by infra-red radiation (National Research Council).

3. Further studies of chemical and inert indicators of forest fire danger (Dominion Forest Service). 
4. Investigation of indicators of electrical conductivity and magnetic field strength for fuel moisture content determination (Dominion For. est Service).

5. Establishment of a fire-hazard research station in the Whiteshell Forest Reserve, Manitoba, for adapting the Wright system to forest and fuel types associated with the Pre-Cambrian area (Manitoba and Dominion Forest Services).

6. Continued fire-hazard research at the Petawawa and Kananaskis Forest Experiment Stations, and analysis of New Brunswick fire records (Do. minion Forest Service).

7. Continued work on determination of standards of adequate forest-fire protection in Canada (Dominion Forest Service).

8. Issue of periodical bulletins on new developments in forest-fire protection, if staff available (Associate Committee on Forestry, National Re. search Council, and Dominion Forest Service).

Prevention

9. Continued study of chemical treatment of fire-guards (Dominion Forest Service).

Detection

10. Use of bolometers for fire detection by infra-red radiation (Ontario Dept. of Lands and Forests; National Research Council).

11. Tests of Army No. 5 smoke generators (National Parks Service).

Communication

12. Further development of remote control radio stations and use of higher power transmitters (British Columbia Forest Service).

13. Design and development of light-weight portable radio set according to specifications prepared by conference of Dominion and Provincial representatives, if facilities are available.

Fire-Fighting Equipment and Methods

14. Investigation of new fungicides for mildew proofing hose (Ontario Dept. of Lands and Forests).

15. Tests of Wright hose vulcanizer (Dominion Forest Service).

16. Further tests of fog nozzles (Ontario Dept. of Lands and Forests; Do. minion Forest Service).

17. Further trials of wetting agents and other chemicals for the control of deep-burning fires and mopping-up operations (Ontario Dept. of Lands and Forests; Dominion Forest Service).

18. Continued experiments with tractor-and-plough combinations for fireline construction (Manitoba Forest Service).

19. Investigation of the fire-control possibilities of rain produced artificially by "sceding" suitable cloud formations with dry ice. (Manitoba For. est Service).

H. W. BeaLl, Chairman

J. R. Johnston, Secretaty 


\section{FOREST PATHOLOGY}

The Committee is composed as follows:

Maritime Provinces: A. J. Skolko

Quebec: R. Pomerleau

Ontario: J. E. Bier (Chairman), C. G. Riley (Secretary), A. W. McCallum, W. R. Haddow

Prairie Provinces: C. B. Gill, H. L. Holman

British Columbia: H. W. Eades, R. E: Foster, F. S. McKinnon, J. M.

Mottishaw, R. E. Smith, D. C. Buckland (Acting).

All members have contributed directly or indirectly to the following reports.

A. J. Skolko, Dominion Forest Pathological Service, Fredericton, N.B. Die-back of birch

Studies on this problem were continued in 1947 as a co-operative project betwcen the Dominion Forest Pathological Service, and the Nova Scotia De. partment of Lands and Forests. The results are being prepared for publication.

Deterioration of fre-killed pulpwood stands region.

Field studies on this problem were continued in the Lake St. John

Teaching

In return for accommodation and facilities provided by the University of New Brunswick, Dr. Skolko is continuing to conduct the course in forest pathology given to the senior class in the Faculty of Forestry.

Publications

Skolko, A. J-Deterioration of fire-killed pulpwood stands in Eastern Canada. For. Chron. 23: 128-145. June, 1947.

\section{R. Pomerleau, Querec Division of Forest Pathology}

Dutch elm disease

During 1947 the Division of Forest Pathology of the Department of Lands and Forests did not actively participate in the survey and the removal of diseased elms in Quebec. Most of our efforts were concentrated on research projects on this disease. Investigation on the rate of spread of the disease were carried on in 5 sample plots of one square mile each established last year, and in another one measured this year. All the elms inside the plots and outside within a radius of one mile were closely examined twice during the summer. To determine the period of susceptibility of the elm to the fungus, 10 trees were again this year inoculated each week from early spring to late fall. All the trees inoculated last year were removed and the development of the fungus studied in the laboratory. This project was completed by a study of the effect of the number of spores and the last year number of inoculation points. The investigation initiated on the cambial activities of the elm throughout the season, the period of the year when the emerging beetles carry the fungus spores, and the antibiotic effect of some bacteria on the same organism, were continued this year. 
The outbreak of this disease now covers an area of about 9,000 square miles in 32 counties of the Province of Quebec. Since 1945, most of the diseased trees found were cut down by owners. Pending results of research projects under way, it is felt that the present procedure of scouting and tree removal should be continued. However, to insure a better control, a more complete survey and more rapid removal of infected trees and breeding material for beetles would be most desirable.

Other projects

Last year, severe damage was found at Valcartier in a red pine plantation. Two-thirds of the 3,000,000 red pines planted before the war were killed or badly injured by early freezing which occurs frequently in this frost pocket. Investigations into this trouble are under way.

Extent and intensity of the dieback of birches in Quebec were followed again this year. More than 25 sample plots were established in various localities to determine the relationship of the shallowness of rooting with the degree of dying.

Publications

Pomerleau, René. Means of inoculation of the Dutch elm disease by Hylurgopinus rufipes Eich. Can. Jour. Res. C, 25: 102-104. 1947.

Pomerleau, René. Rapport général des travaux effectués sur la maladie hollandaise de l'orme dans la province de Québec en 1946. Service forestier, Québec.

Pomerleau, René, $\&$ Hubert Lechevalier. Etude de l'effet antibiotique d'une bactérie sur le développement du Ceratostomella Ulmi

(Schwartz) Buis. Revue Canadienne de Biologie 6: 478-484. 1947.

A. W. McCallum, Dominion forest Pathological Service, Ottawa

Developments in the programme of expansion of the Dominion Forest Pathological Service are as follows: A new unit has been established with headquarters at Toronto, to serve the requirements of Ontario. Dr. J. E. Bier has been transferred from Victoria to take charge of this unit, leaving Dr. D. C. Buckland as Acting Officer-in-Charge of the Victoria unit. Also transferred to Toronto were V. J. Nordin from Victoria, and L. T. White from Ottawa. These two, and R. E. Foster of the Victoria unit, are taking graduate studies in forest pathology at the University of Toronto.

The Dominion Forest Pathological Service now has three regional units serving the Maritimes, Ontario, and British Columbia. The Province of Quebec maintains its own Service. Thus, the Prairie Provinces remain the only large region to which no forest pathologists have been assigned, and it is planned to establish a unit there as early as possible. To this end, a preliminary reconnaissance of forest pathological conditions in that region has been made by Dr. C. G. Riley.

At the Ottawa Headquarters of the Dominion Forest Pathological Service, in addition to administration of the three regional units, the following projects have been conducted:

Dutch elm disease-A. W. McCallum

Scouting for this disease was carried on by the Dominion Government on about the same scale as in previous years. In Ontario the seven eastern 
counties, Carleton, Russell, Prescott, Glengarry, Stormont, Dundas, and Grenville were intensively scouted. Farther west, less intensive surveys were carried out between Highways No. 2 and No. 7 and between Toronto and Hamilton along Highways No. 2, 5 , and the Queen Elizabeth. North from Toronto, scouting was done from Highway No. 11 as far as Gravenhurst and north-west from Hamilton along Highway No. 8 to Goderich. The region between Highway No. 8 and Lake Erie was scouted from Windsor, London, and Niagara Falls. In the Niagara Peninsula a considerable amount of intensive scouting was done. Not a single instance of Dutch elm disease was discovered as a result of this work.

In Quebec, the area of infection was enlarged somewhat, as a result of work done this year. The extreme dimensions of the area as known at present are about 195 miles by 105 miles. In the western part of the infected area there was some extension and intensification of the disease in the counties lying north of the Ottawa River. The disease was found in Argenteuil County for the first time when five infected trees were located. The nearest of these are only about three miles in a direct line from the Ontario border. In the eastern and south-eastern part of the area, infection was considerably intensified in Lotbiniere, Richmond, and Megantic Counties. A total of 840 infected trees were found this year in Quebec. This com. pares with 2100 in 1946 and 1349 in 1945. However, the figure for this year does not indicate a decrease in the frequency of infection as this year's results are not directly comparable with those of the two preceding years. The policy of eradicating diseased trees is being continued, with the exccption of the severely infected area about Sorel where eradication has become impracticable by the methods in use.

Herbarium, reference collection of pure cultures, and cultural studies of wood. destroying fungi-Mildred $K$. Nobles and Ruth Macrae.

These are continuous projects that are conducted as a service to all the regional units. These services play an important part in all projects concerned with heart-rots, especially in the determination of causal fungi. Dr. Nobles is preparing a bulletin on the cultural identification of wood-destroying fungi.

Subcommittee on Forest Tree Breeding, National Research Council-C. G. Riley

-Resistance of white pine breeding stock to blister rust

The white pine breeding materials in the old disease garden at the National Research Council Annex were examined in May of this year, prior to their removal to the new site at Connaught Range. These materials comprised 46 lots totalling approximately 2,300 trees, of which 259 trees representing 32 lots were infected with blister rust in various degrees of intensity. Fourteen lots remained apparently free of the disease, which should not be interpreted as necessarily indicating resistance.

-Resistance to rust in poplar breeding stock.

Poplar breeding stock in nurseries and plantations have been examined one to three times per year for up to seven years, to determine the degree 
to which they have been infected by rust (Melampsora medusae) and other diseases. In all, there have been 608 lots of stock, many of which have been under observation since this work was initiated. The lots comprise from one to several hundred trees. The field data for all the examinations have now been consolidated and the results are being summarized for the information of the geneticists.

Programme at the Petawawa Forest Experiment Station-C. G. Riley -White pine blister rust

Surveys made in nine stands revealed that 15 per cent of the white pines of 8 inches D.B.H. and larger were fatally attacked by blister rust. These trees will eventually be killed by the disease. An additional 2 per cent bore rust cankers in such a position on the branches that they probably will be eliminated by the death of the branch before they reach the trunk of the tree.

Twenty-four of the Permanent Sample Plots of the Dominion Forest Service were examined, and the condition of every white pine with respect to blister rust was noted, e.g. if infected, position and size of canker, degree of girdling, etc. With the aid of these records it will be possible, by periodic re-examinations, to learn something of the rate at which rust cankers enlarge, the number of years required for the fungus to grow down a branch under various conditions and infect the main stem, and the subsequent number of years required to girdle and kill the tree. These examinations will also yield data regarding incidence of new infections and other basic information. An additional object of this work is to provide information essential to the primary purpose of the sample plots, i.e., principally, yield as related to various silvicultural treatments. - Poplar diseases in relation to thinning

Eight Permanent Sample Plots, established by the Dominion Forest Service for studying the effects of thinning poplar, were reexamined in 1947, for the purpose of studying the relationship betwen the incidence of disease (especially Hypoxylon canker and sun scald), and the respective silvicultural treatments and other conditions. The results of previous reexamination (1940) showed that damage from sun scald was appreciably greater on the thinned plots. Concerning Hypoxylon canker, an unexpected finding was that the incidence of this disease was generally higher on the thinned plots than on the unthinned controls. The results of the 1947 re-examinations have not yet been analysed.

Reconnaissance in the Prairie Provinces-C. G. Riley

As a result of increasingly urgent requests for investigations into forest pathological problems in the Prairie Provinces, a preliminary reconnaissance was made in 1947.

Expeditions were made into as many stands as circumstances permitted. Travel was mostly by car, supplemented by truck and air transport provided by the Provincial Governments, to points not accessible by summer roads. Forest pathological problems were discussed with forest administrative personnel at every opportunity, and in every instance $I$ found these officers keenly interested and anxious to cooperate in showing me their various 
stands and discussing their problems. In fact, one of the main difficulties encountered, was to break away from a given district and move on. On my part, I was greatly impressed by the extent of the forests and, especially in the great mixedwood belt, the rate of growth and the size of the trees. It is my strong impression that the Prairie Provinces possess a potential forest industry that when developed, will compare very favourably with that of any other part of Canada.

Regarding forest diseases, these are, in general, of a similar nature to those found throughout Canadian forests. Throughout the region as a whole, heart rots are the source of greatest concern. In all species there is urgent need of information regarding age-site-decay relationships. The urgency of this requirement arises from the fact that preparations are being made to place large additional areas under management on a sustained yield basis, e.g., the Dore-Smoothstone Lakes area in Saskatchewan, and the area recently placed under the control of the Eastern Rockies Forest Conservation Board. Data on cull per cent are needed not only for purposes of forest inventories, but also in deciding upon rotations and cutting cycles.

The most striking disease encountered was mistletoe brooming of jack pine, which presents a serious problem in the silviculture of this species. The same disease occurs also on lodgepole pine, but I did not visit any of the severely infected localities. Although jack pine occurs in extensive stands from northeastern British Columbia to the Atlantic Coast, its mistletoe is not known to occur in the East. There is no known reason why this parasite should not occur throughout the range of its host, and it is a matter of importance that a careful check should be maintained regarding the possible spread of the disease eastward.

Several disease problems occur in nurseries, windbreaks, and shelterbelts. Among the more important of these are cankers and other diseases of poplars and spruce trees, seedbed diseases of spruce, and fungous attack of lifted planting stock in winter storage.

Among the numerous diseases of lesser consequence were a heavy attack of rust (Chrysomyxa ledicola) on white spruce in Manitoba, and galls and cankers of jack pine caused by rust fungi of the genus Cronartium.

\section{Publications}

Riley, C. G. Heartrot of oaks caused by Polyporus obtusus. Can. J. Res., C. 25: 181-184. Oct. 1947.

J. E. Bier, Dominion Forest Pathological Service, Toronto

At present, this unit is housed in the Department of Botany, University of Toronto. In return for this accommodation the laboratory is responsible for the instruction in forest pathology to the senior class of the Faculty of Forestry. This would appear to be an excellent arrangement since several members of the graduating class have expressed a desire to become employed in forest pathology subsequent to graduation. The Toronto unit now employs eight persons on a year-round basis, including three graduates in forest pathology. Two of these, namely, Messrs. L. T. White and V. J. Nordin are at present continuing their graduate work at the University of Toronto. 
The summer of 1947 was spent in surveying the field in Ontario to arrive at a programme of work which would be centered around the projects which require immediate attention. It is gratifying to report that in every instance the forest interests recognized the importance of our work and expressed their willingness to cooperate and assist in the further prosecution of our studies. The authorities contacted included representatives from the Ontario Department of Lands and Forests, Dominion Forest Service, Lumber Industry, Pulp and Paper Industry, Faculty of Forestry, University of Toronto; Ontario Department of Mines and the International Nickel Company.

As a result of this initial survey, general agreement was reached that in Ontario investigations should be made and continued on the following projects during 1948:

White Pine Blister Rust

Blister rust surveys in 50-to 70-year-old stands of white pine near Dorset, Barry's Bay, and Mattawa, Ontario, demonstrated that from 15 to 20 per cent of the trees of merchantable size are now fatally infected with this disease. On a volume basis the fatally infected trees comprise approximately 20 per cent of the total merchantable volume of the white pine in these stands. Disease surveys will be continued, to locate the optimum areas for the continued growth of white pine. Emphasis will be placed on recommendations which will assist in the future management of these types.

Decay in Relation to the Utilization and Management of Overmature Stands of White Pine-L. T. White.

It is estimated that 69 per cent of the merchantable white pine in eastern Canada $(5,885,000,000$ board feet) is located in Ontario. This indicates the importance of this tree in the forest economy of the Province. At present a major part of the commercial cutting of white pine is located in overmature stands, which in many instances are reported to contain ab. normal volumes of defect. Pathological investigations are under way to determine the relationships between disease and tree age, diameter, site, etc. Such studies will provide the forest interests with information regarding the maximum utilization from present stands and will provide local net volume tables, which are of value in the preparation of forest inventories and plans for cutting.

Decay Relationships and Deterioration in Spruce and Balsam

In cooperation with forest pathologists of the United States Department of Agriculture, a comprehensive study will be undertaken in 1948 to determine the rate of deterioration and floatability of insect-killed spruce and balsam. Concurrently with these studies information will be acquired, which will indicate the decay losses in living stands in an effort to determine the gross and net merchantable volumes per acre in stands of different ages and on different sites.

Decay in Relation to the Utilization and Management of Maple-V. J. Nordin

A large percentage of the forested area in the Ottawa-Huron region of Ontario is comprised of stands of tolerant hardwoods, predominantly maple. 
In many instances the original forests were of a pine type, and one of the most important problems of forest management in this region consists of devising some method of converting the inferior hardwood types to softwood types. The University of Toronto forest at Dorset is in this region. At present a management plan is being constructed for this forest, which will include recommendations for the utilization of maple. Although it is well known that in certain areas maple is subject to heavy losses from defect, no pathological information is available which would indicate the net volumes per acre, which may be recovered from trees of different ages and on different sites. An investigation is under way to obtain pathological recommendations for inclusion in a management plan.

Needle Blight of White Pine

White pines of all ages in Ontario are subject to a disease known as needle blight, which kills all foliage of the current year's growth on infected trees. The cause of the injury is unknown, and in the Sudbury and Tem. agami regions doubt exists as to whether white pine is affected by needle blight or fume injury, which produces similar symptoms. Experiments will be undertaken in an effort to determine the cause and extent of needle blight and to describe the factors which may be used to distinguish this disease from authentic fume injury.

W. R. Haddow, Ontario Department of Lands and Forests, Toronto Blister Rust of White Pine

In connection with the assessment of the status of blister rust disease in forests of Ontario, the decennial reconnaissance of the Algonquin Park areas gave the following results for the Petawawa Drainage area: About ten per cent of all living white pines over $4 \frac{1}{2}$ feet tall were rusted; of those 7 inches D.B.H. and over, fifteen per cent were rusted. The number of rusted pines has doubled in ten years. Since 1937 about five per cent of all stems have been killed by rust; but in the larger sizes the proportion is less than in the smaller. In the last ten years trunk infections have increased more than threefold, and for trees now 7 inches D.B.H. and up, they have increased seven or eightfold. Branch infections have more than doubled in number, but do not appear to have multiplied in the smaller trees. In well stocked stands, ingrowth has maintained the density of stocking which ex. isted heretofore.

Study of certain phases of infection of pine was undertaken. Observation over a period of years will be maintained.

Periodic observations of canker development yielded some information on the rate of development of cankers, and mortality in diseased trees. The work suggests that recovery from infection through natural trunk clean. ing is more common than some had thought; and emphasizes the importance of stand maintenance in pine silviculture.

An interesting indication of the trend of opinion with respect to blister rust control practice and administration of same (and indeed, with broader reference) is given in the following article, which can be read with advantage by all foresters and others interested in forest disease problems: Billings, Roger W. Future forest tree disease control with special reference to blister rust. Jour. For. 45: 8, 586.589, 1947. 
H. W. Eades, Dominion Forest Products Laboratory, Vancouver

The Timber Pathology unit has moved into new quarters, and there are encouraging indications of expansion in the service.

D. C. Buckland, Dominion Forest Pathological Service, Victoria

In addition to changes in personnel as already noted, this unit reports upon the following projects. As these studies usually require more than one year to complete, the results to date are mimeographed in the form of interim reports so that all known information is available for those interested. Decay in Relation to the Management of Western Hemlock on the 2ueen Charlotte Islands, B.C. (mimeographed interim report) -R. E. Foster

The study of decay in western hemlock on the Queen Charlotte Islands was organized in 1945 at the request of the forest industry. Hemlock comprises over 45 per cent of the total merchantable volume in the area and it was hoped to manage the stands on the Islands as a permanent pulp unit. To date 1,767 trees containing over 2 million board feet have been examined in detail. The total loss from decay was found to amount to 28.4 per cent. Decay in Relation to the Management of Western Hemlock and Balsam Fir in the Franklin River Area, V.I.-D. C. Buckland

This study carried out in cooperation with the Bloedel, Stuart and Welch forestry staff has been completed and is now in the process of publica. tion.

Decay in Northem White Spruce in the Upper Fraser Region (mimeographed interim report) $-R$. A. Waldie

The spruce-balsam type of the Upper Fraser Region has an estimated merchantable volume of 9 billion board feet. Previous investigations by the unit have covered balsam fir in the region. White spruce comprising over 80 per cent of the wood cut in this forest type, is now under investigation to complete pathological management plans for the area. Five hundred trees have been analyzed to date.

Decay of Cottonwood at 2uesnel, B.C.-G. P. Thomas

The cutting of cottonwood for plywood and other uses has greatly reduced the accessible stand of this species. It is highly desirable that the condition of the remaining stands and an accurate knowledge of the pathor logical rotation be obtained. In cooperation with Western Plywoods Limited, a study has been started to determine the age-decay relationship in the species so that pathological management plans may be worked out. This project will be continued in 1948 .

Decay of Douglas Fir on the East Coast of Vancouver Island-J. W. Roff

Following requests from the forest interests a study of the effect of decay on the management of Douglas fir on the east coast of Vancouver Island was started. To date 680 trees have been analyzed. This study will be continued in 1948.

White Pine Blister Rust Disease in the Nelson Forest District, B.C. -D. C. Buckland, J. W. Roff and G. P. Thomas

Following a preliminary investigation in 1946 of the white pine blister rust disease in the Nelson Forest District, the B.C. Forest Service asked that a more comprehensive survey be made to work out a possible manage- 
ment plan for white pine in the Region. During the past summer an intensive investigation was made with the cooperation of the B.C. Forest Service. The results are in the process of compilation. Permanent study plots were established for studying the rate of increase of the disease, by Mr. W. A. Porter.

"Blow-down" in Douglas Fir, Skutz Falls, B.C. (mimeographed interim report)-D. C. Buckland, J. W. Roff and G. P. Thomas

It was requested that a stand of 80-year-old Douglas fir at Skutz Falls, V.I., B.C., reported as "blow-down" be investigated as the nature of the remaining stand indicated that some factor other than wind was responsible for the loss of the trees. Seventeen hundred trees were analyzed and it has been found that the root rot organism, Poria Weirii Murr. was responsible for the greater part of the loss while considerable damage was caused by Poria subacida (Pec.) Sacc. and Stereum sanguinolentum, Alb. and Schw.

Fusarium Top Blight of Douglas Fir Seedlings, at Duncan, V.I. (mimeographed interim report) $-D$. C. Buckland

A disease causing severe loss in Douglas fir seedlings at the Duncan Forest Nursery was investigated in cooperation with Mr. J. Long, Superintendent of the Nursery, B.C. Forest Service. A detailed study of the effect on control of the disease on fifteen different treatments laid out by Mr. Long involving various nursery bed rolling pressures, chemical additions to the soil surface, cover soil treatments and soil treatments was carried out over a 100 -day period during the past summer. In check beds 50 per cent of the seedlings were killed by the disease in the 100-day period. Control experiments indicated that the use of hardwood sawdust on top of the cover soil and the use of an imported cover soil, lighter and containing more organic material than the nursery soil, brought about reasonable control.

Publications

A number of studies carried out by the Victoria unit and previously distributed as mimeographed interim reports have been published as follows:

Bier, J. E., R. E. Foster and P. J. Salisbury. Studies in forest pathology. IV. Decay in Sitka spruce on the Queen Charlotte Islands. Dom. Dept. of Agr. Tech. Bull. 56. 1946.

Bier, J. E., P. J. Salisbury and R. A. Waldie. Studies in forest pathology. V. Decay in fir in the Upper Fraser Region of B.C. Dom. Dept. of Agr. Tech. Bull. (in press).

Bier, J. E. and D. C. Buckland. Relation of research in forest pathology to management of second growth trees. 1. Poria Weirii root rot, an important disease affecting immature stands of Douglas fir. B.C. Lumberman. Feb. 1947.

Bier, J. E. Handbook on tree diseases of British Columbia. Dom. Dept. of Agr. Tech. Bull. 28 plates (in press).

Salisbury, P. J. Fungi causing decay in balsam in the Upper Fraser Region, B.C. Phytopath. (in press).
J. E. BIER, Chairman.
C. C. RileY, Secretary. 


\section{REFORESTATION}

During the past few years this committee has attempted to gather together all the information available on the use of mechanized equipment in forest nurseries and on planting projects. Although nothing spectacular can be reported this year steady progress has been made and new innovations in machinery are proving practical. The Ontario Forest Service, which used a tree planting machine for the first time in 1946, now has six in operation with more on order. The few men required to operate each machine and the increased speed of planting has done much to offset the difficulty in obtaining labor and to reduce the cost of planting. In British Columbia the soil spreading machine has not proved successful when using damp soil but it can be used efficiently with sand or dry soil and in the spreading of hardwood sawdust for winter mulch. A new root pruning blade attached to a farmall tractor has been developed to replace the heavy and cumbersome root pruner now in use in British Columbia. This single rigid blade has proved very efficient both for root pruning and in lifting trees in the nursery.

The use of infra red lamps in seed extraction by the Ontario Forest Service has given excellent results on an experimental basis and they are now rebuilding their equipment to increase the capacity for use on large scale seed extracting operations.

Experiments with pelleted seed have not yielded any concrete results but projects of this nature require considerable time and effort before any progress is made.

Damping off fungus is ever present in forest nurseries and the problem of combating it is a major one in forest nursery technique. At St. Williams, Ontario losses which had been entirely attributed to damping off were partially due to sun scorch and increased shading has reduced losses to a large extent. At Duncan, British Columbia, a new nursery site had losses due to damping off fungus as high as fifty per cent. Experiments were carried on with surfacing rolling pressures, chemical additions to the soil, imported soils and use of hardwood sawdust. Of all these, the use of hardwood sawdust as a top covering over imported soils gave the most promising results. Details of these experiments may be obtained from a published report by Dr. D. C. Buckland, of the Dominion Forest Pathology Laboratory, Victoria, B.C.

Now that reforestation work has been in progress in all parts of Canada for many years some attention should be paid to the results obtained from early plantations and the variation in growth rates for the many different species used. On the Prairie areas of Western Canada the adaptability and growth of various tree species has been quite definitely established at the Dominion Forest Service Stations. Over the past forty years more than two hundred million trees have been distributed to farmers for shelter-belts. Owing to the slow growth in these areas the farm woodlot is primarily for protection from wind with only a small return of wood products over a long period of time. Of the great variety of trees planted Russian poplar and cottonwood give the best height growth although Green Ash, White Elm and Manitoba Maple are also favored among the deciduous trees planted. 
With conifers the Siberian Larch was outstanding in rate of growth and possibility for utilization. White and Colorado Spruce have proved excellent for shelterbelts but Scots Pine, although showing good growth, has such poor form that it is not recommended for use. White Pine, Yellow Pine and Douglas Fir have had the slowest growth rate under Prairie conditions. General interest in farm tree planting continues to expand and six million trees are being distributed annually to approximately six thousand farmers. With forty per cent of the farms in the Prairie Provinces still barren of trees, this demand will probably increase each year.

In British Columbia Douglas Fir has been planted almost exclusively although a number of experimental areas have been planted with a variety of other species. Natural regeneration of Western Hemlock and Red Cedar with planting of Douglas Fir results in a mixed stand similar to the areas logged.

Experimental planting with Yellow Pine gave good results for the first ten years but after that mortality was high and growth very slow. Scots Pine plantations also grew rapidly but most trees have very poor form. Other exotic species suffered from frost damage in the nurseries so that up to the present no trees have been grown that could compete with the native trees that grow along the coast of British Columbia.

A memorandum submitted by C. A. Edwards, Indian Head, Saskatchewan, is part of this report. This memorandum was published in the Forestry Chronicle, Vol. XXIV, June 1948.

H. G. MCWilliams, Chairman.

G. A. Mulloy, Secretary.

\section{SILVICULTURE}

After being seriously curtailed during the war years, research activities of all agencies were back to normal last year. If the research programme continues to expand as it has during the last few years it augurs well for the future of silviculture.

The Silvicultural Committee has been re-organized and the membership is now as follows:

A. P. MacBean, Parksville, B.C., Chairman.

E. Bonner, Kapuskasing, Ont., Secretary.

A. P. Leslie, Toronto, Ont.

E. H. Garman, Victoria, B.C.

W. M. Robertson, Grand Falls, Newfoundland.

Dr. Andre Linteau, Quebec, Quebec.

J. C. Veness, Fredericton, N.B.

H. L. Holman, Calgary, Alberta.

J. R. Walton, Chicoutimi, Quebec.

R. C. Hosie, Toronto, Ontario.

G. A. Mulloy, Ottawa, Ontario.

As now constituted, the Committee has a good representation from all parts of the country and from government agencies and private enterprise. 


\section{Dominion Forest Service}

Since the end of the war, the Silvicultural Research Division has resumed its normal activities in the fields of silviculture and forest management. W. M. Robertson, who was chief of the division for many years, has retired and is now in charge of silvicultural research work for the AngloNewfoundland Development Company at Grand Falls, Newfoundland. He has been succeeded by G. A. Mulloy, his former assistant. The staff has been supplemented by the acquisition of additional technical and non-technical staff and is still in the process of expansion and re-organization. The five experimental stations, comprising about 240 square miles of forested land in representative areas across Canada, and the district offices in the Maritimes, Quebec, Manitoba, and Alberta have had an active programme of research. All of the research projects are being reviewed to assess their status and potential value. Major projects under study include reproduction surveys, empirical stand density yield tables, preparation and revision of working plans, the study of growth and stand development on experimental cutting and observation areas, development of plantations, and the revision of two standard publications which are out of print. Co-operation with the Department of Agriculture has continued, particularly in the fields of tree breeding, spruce budworm control and demonstration farmers' woodlots.

Large scale reproduction surveys of cut-over and burned-over lands were started across Canada in 1946 at the request of the Canadian Pulp and Paper Association. Reproduction and advance growth were tallied in a standard method by species on the basis of stocked milacre quadrats and recorded in the field by a punch-card system which greatly simplified office sorting and compilation. Only preliminary results are available since the survey is not yet completed but it appears evident that: (1) fire following logging is almost invariably disastrous to the establishment of a new stand; (2) generally spruce and balsam reproduction in the Maritimes and in most of Quebec and Eastern Ontario is quite satisfactory following logging; while in Alberta, Saskatchewan and Manitoba the reproduction is usually poor. More detailed regeneration studies on permanent plots are being carried out to complement the general surveys; the development of the reproduction can thus be followed over a period of years so that the influence of such factors as condition of seed bed, site, cutting methods, and competition from other species, etc., can be appraised. This phase of the work is being conducted mostly in Alberta, Manitoba, and Ontario.

A method of developing empirical yield tables particularly adapted to large areas containing understocked and mixed stands has been developed and appears to have promising possibilities. It is based on the stand density index (computed from the average diameter and number of trees per acre), and the changes in stand density and composition as determined from the remeasurement of permanent line-plots.

Working plans for the experimental stations and for the Riding Mountain National Park are being revised. Aerial photographs to provide accur. ate type maps are being used extensively for this work. 
The remeasurement of permanent line-plots established on areas cutover commercially during the past thirty years and which have been set aside as observation areas, has yielded information as to the growth and development following logging. Similar information is available from lineplots in both disturbed and undisturbed stands on the forest experiment stations. Several reports are now being prepared on the results of the work. A new area was established near Forestville, Quebec, in 1947, to study regeneration and growth of pulpwood species after mechanized logging, normal logging, and fire following logging.

A survey was made of a 7000 acre plantation area established over a period of twenty years by the Laurentide Pulp and Paper Company on marginal agricultural land near Grand'Mere, Quebec. The results of this survey are presently being compiled and should yield valuable information as to the possibilities of reforesting areas adjacent to pulp and paper mills.

A revision of "Native Trees of Canada" is in progress and the new edition will include new photographs, range maps and revised nomenclature. Additions and corrections are also being made to "Form-Class Volume Tables." New editions of both publications will be available in 1948 .

Work in tree-breeding has been on a maintenance basis because of lack of staff. An expanded programme in this work will particularly stress the selection of superior strains of native species for good form, rapid growth and resistance to insects and disease.

The establishment of demonstration woodlots in co-operation with the Department of Agriculture and on forest experiment stations has been continued and is particularly valuable for publicity purposes.

The co-operative project on the control of the spruce budworm on the Green River limits of the Fraser Company near Edmundston, New Brunswick, is continuing. For the Forest Service, it is primarily a problem in forest management to determine cutting methods and methods of regulation which will make the forest more resistant to this insect. The cutting of overmature stands is important and much preliminary work has been done in determining existing conditions. The company has removed some fifty thousand cords of pulpwood under the cutting plan.

In addition to the projects outlined above, routine remeasurement work on permanent plots established to study the effect of intermediate and har. vest cuttings, and the development of natural stands and plantations at the various experimental stations and areas has been maintained. Considerable study has also been given to sampling methods for various types of silvicultural work, and to the relationship of form-class to diameter, height, age, and density.

Silvicultural Research Notes

$$
\text { Publications 1946-47 }
$$

No. 78 Effect of Different Methods of Slash Disposal on Jack Pine Re, production.

by J. W. Noakes

No. 79 Thinning Red Pine, Rockland, Ontario.

by G. A. Mulloy 
No. 80 Effect of Thinning Upon the Growth and Yield of Aspen Stands. by A. Bickerstaff

No. 81 Effect of Thinning and Pruning Upon the Form of Red Pine.

by A. Bickerstaff

No. 82 Empirical Stand Density Yield Tables.

by G. A. Mulloy

No. 83 One-tenth Acre vs. One-fifth Acre Plots in Sampling Immature Mixed Stands.

by A. Bickerstaff

No. 84 Sampling Efficiency of Line-Plot Survey. by A. Bickerstaff

Silvicultural Leaflets

No. 22 Balancing Maximum Increment per Tree Against Maximum Increment per Acre. by $A$. Bickerstaff

No. 23 Assessing the Growth of Individual Trees by Radial Increment. by A. Bickerstaff

No. 24 Scaling 16-foot Pulpwood by Stacked Measure. by $A$. Bickerstaff

Miscellaneous

Sample Plot Methods, by W. M. Robertson and G. A. Mulloy.

Misc. Series No. 4

Classification of Silvicultural Research Projects of the Dominion Forest Service.

Misc. Series No. 5

Petawawa Forest Experiment Station.

Forest Tree Breeding in Canada, by J. L. Farrar.

Paper presented at British Empire Forestry Conference, 1947

Forest Ecology in Canada, by G. A. Mulloy.

Paper presented at British Empire Forestry Conference, 1947

Officers of the division also contributed several articles to technical and popular periodicals.

\section{Ontario Department of Lands and Forests}

1. Regeneration Studies - These are a continuation of work started in 1930 and carried out until 1934 with an interruption lasting until 1944. Work has been carried out in all the principal associations of the forest regions of Ontario and a composite report will be issued within a year. Some companies are now doing this type of work thernselves, and an active co-operation exists between them and this Department, and also with the Dominion Government.

2. Soil Studies-These, under the direction of G. A. Hills, aim first at a separation of forest and agricultural soils and secondly at a classification of forest soils by sites for different species with full chemical and physical analysis. 
3. Re-examination of Sample Plots-This work involves study of the sample plots laid down by various companies and by the Department from 1925 to 1930 in different forest types and with different methods of treatment. Sample areas for different treatment are to be set out on Company limits in all the principal types of all forest regrowth.

4. Studies of Direct Seeding-This involves the use of coated and naked seed off direct seeding of burned and cut-over land. Some 1500 acres have been seeded in this way and results should be available in two years. The coating of seeds for protection from insects and fungi and a measure of protection from rodents and birds on a laboratory scale has some promising aspects. Definite important increases in survival due to improved protection from fungi and insects appear to be certain. Important protection from mice is less likely but there is some improvement even here. The coated seeds are definitely less attractive to squirrels. Work is going ahead on the addition of trace elements to the coating and the selection of the best type of fungicide to use. Germination of seeds on the surface of the ground appears to be improved. There appears, also, to be a definite increase in the life of the seeds in ordinary storage. This amounts to an extended period of dormancy and fully after ripened seeds must be used for coating or they must be treated specially after coating to break dormancy. Ordinary stratification is not possible with the coated seeds and a method of using a refrigerator with temperatures alternating from $32^{\circ}$ to about $70^{\circ}$ is being tried out. Some success has already been attained.

A dye treatment is being tested for quick determination of the propor. tion of viable seeds in a lot. This may replace the cutting and other tests now in use.

5. Studies of the production and value of conifer leaf oil are being started in co-operation with the Ontario Research Foundation. Although this is not primarily a research project it will ultimately tie in closely as it, if successful, will introduce a new by-product and result in the removal of more slash from cut-over areas.

\section{University of Toronto}

In co-operation with the Research Division, Department of Lands and Forests of Ontario, a study was started on the University forest on the regeneration of white pine.

\section{British Columbia}

This report deals with the work of the B.C. Forest Service. The results of work done by industrial companies to improve silvicultural conditions in their forests have not yet been received. During the past year Forest Service studies were concerned mainly with growth and yield, site-type classifications, and stand improvement measures.

Experimental plots established in 1929 at Cowichan Lake Experiment Station were thinned for the third time at 35 years of age. Low and crown thinning removed nineteen to twenty-five per cent of volume. It appears that on average Douglas fir sites thinnings removing twenty-five per cent, or even more, of volume before thinning is entirely practical. Stands 
in this type previously untreated at 30.40 years of age require crownthinning, changing to low thinnings for later intermediate cuttings.

Thinning linked with pruning treatment aims at improving the quality and yield of the total crop. The two treatments are essential if clear lumber is to be produced in stands to come under forest management during the next rotation. Pruning appears to offer satisfactory returns to the forest owner, if done when the diameter of pruned sections is about four inches. From our studies the initial cost of pruning is approximately 14 cents per tree. At 100 years of age this investment will produce 38.0 cubic feet, or 300 b.f.m. of clear lumber on each of the one-hundred largest trees per acre on a good site. Additional guides have been gleaned from the study of pruning methods at Green Timbers Forestry Station (Forest Service Report, 1946:p.19) and the study commenced in 1930 at Cowichan Lake Experiment Station. These tests have shown that cost of pruning varies with the size and toughness of branches. Index figures based on the area of pruned knots per tree, were related to time-cost per pruned foot. It was found that a good estimate of cost can be obtained by sampling the number and size of branches to be pruned. From these measurements an average branch index is found and referred to a curve of pruning time. A plantation pruned to 13 feet in two stages at thirteen and seventeen years old, on a good site, took 0.57 minutes ( 34.5 seconds) per foot of pruned length. A similar pruning in one operation on trees at seventeen years took 0.51 minutes per foot for pruning, plus 0.13 minutes for walking and cleaning saws. In these tests the handsaw and ladder method was used. Trees pruned by this method healed faster than when tree-pruners or pole-saws were used because the branch is removed without leaving a stub. Pruning in winter resulted in rapid healing during the following summer when production of clear wood was quickly obtained, and no infection of the wounds was experienced. Saw'pruned Douglas fir healed 80 per cent of the knot-area in two seasons, and 90 per cent of the trees healed completely in four years, on the basis of external measurement of knots on sample trees. In the Cowichan Lake study pruned trees, sectioned after healing was complete showed faster occlusion of live-pruned knots than over wounds made by removal of dead branches. Healing after live-pruning took one to five years, but after dead-branch pruning four to six years, and occasionally over ten years were required for the production of clear-wood. The incidence of pitch inclusion was very low on smooth saw-cuts.

Direct seeding of hemlock (Tsuga heterophylla), and cedar (Thuya plicata) was tested by an experimental broadcast on a north slope of Hill 60, Cowichan Lake Land District, in 1946. A small amount of seed $(1 \mathrm{oz}$. $\mathrm{H} \xi 11 / 2$ oz. C.) was mixed with three cubic feet of sawdust for seeding each acre. A cyclone seeder was used with a capacity sufficient for covering a quarter-acre. A satisfactory distribution of seed was obtained, but sawdust is not a suitable carrier for use in this seeding machine. Twenty acres were seeded on melting snow at 2,500 feet elevation on May 1st. The area had been logged and burned eight years previously. On this site there was a general cover of willow, or bunchberry (Cornus Canadensis), with natural 
hemlock, cedar and Douglas fir on one-quarter of the total area. At the end of two growing seasons, on the basis of the minimum stocking of $1 \mathrm{M}$. per acre, 57 per cent of the area was occupied by artificially seeded hemlock and cedar, survival being 650 hemlock and 500 cedar per acre on the basis of total area. This survival, in terms of viable seed sown, was 6.5 per cent for the hemlock, and 2.5 per cent for cedar. The seeding of this twenty acre plot by cyclone-seeder method was considerably faster than obtained in previous experiments with broadcasting cedar and hemlock, in this case the area was seeded at the rate of one acre per man-hour.

Site-type classification by vegetation was briefly described in our notes last year and published in the Report of the Forest Service for 1946. The report has since been issued as Publication T30 of the B.C. Forest Service, entitled "Forest Site Types of the Pacific Northwest" by R. H. Spilsbury, and D. S. Smith. Work in 1947 was confined to filling out weak data in the classification. Site studies, based on plant indicators have been started on logged and burned areas. A preliminary trial showed an excellent correlation between stump diameter of the dominant trees at 150 years and site type, as determined from the vegetation of adjacent timbered site. Using stump diameters as a criterion of site it is now planned to study vegetation associations in areas far removed from marginal stands of timber.

\section{MENSURATION}

In 1947 all growth-study plots measured were in the Coast Region. Eighteen new plots covering various degrees of stocking were established in the Hemlock, Spruce, Cedar mixtures. There are now 616 growth and yield plots throughout the Province.

The data from the permanent plots is being analysed to determine the relationship between growth increment and mortality in the different diam. eter classes. The loss from mortality is equivalent to $1 / 4$ to $1 / 3$ of the net increment and occurs in all crown classes. How to reduce this loss by intermediate cuttings is being investigated. A complete analysis of the data from the permanent plots (some have been under observation for twenty-five years) has been stepped up since the war and the work will be accelerated as further staff becomes available.

A party working in the forest types of the north coast made studies to determine the productive capacity of the various sites.

The more important yield tables prepared by the Forest Service and published at various times were mimeographed, and assembled under one cover together with suggestions for their application.

A series of volume tables based on tree diameters, stand ages and site classes have been prepared for second growth Douglas fir and Western Hemlock. Having determined the age and site class of a stand the volume can be obtained directly from the tables without preparing D.B.H.height curves.

Net site class volume tables in cubic feet and board feet have been prepared for the more important species occurring in the old growth stands in the coast and northern interior. These tables allow for average defect and breakage. In cruising all living trees are tallied and the net volume for each diameter class is read directly from the tables. 
To determine the top diameters utilized in old growth, timber data from various logging operations have been analysed. The top D.I.B. as related to D.B.H. is best expressed by the formula Top D.I.B. = $\mathrm{a}$ - bD.B.H., O.B. For average ground conditions the top diameter utilized is equal to $2-4.2$ D.B.H. About $3 / 4$ of the total variance in top D.I.B.'s is associated with D.B.H. and $1 / 4$ with miscellaneous factors. The studies show that the top diameters used in our standard table are satisfactory for cruising old growth coast timber. Tables based on a uniform top would be less satisfactory for our conditions where trees vary greatly in size.

The use of the cubic foot as a basis of measurement is being adopted as rapidly as conditions permit. A series of tests with immature trees of several species indicated that the formula $\mathrm{V}-\mathrm{B} 1 / 3-\mathrm{H}$ gives the total cubic contents of the tree with a high degree of precision, where $\mathrm{V}=$ Volume in cubic feet, B $1 / 3=$ Basal area at $1 /$ the height and $\mathrm{H}=$ total height of the tree. The use of this formula in cubing trees results in a great saving in time over most methods in general use.

Intensive studies have been made to determine the relation between cubic foot-scale, board foot scale and mill tally. The over-run varies greatly depending on diameter of logs, length of logs, size of timber, type of mill and the efficiency of the sawyers. These factors also effect the cubic foot-mill tally ratios.

The most equitable method of scaling is to measure logs in cubic feet and let the manufacturer apply a factor to suit particular plant and product.

A preliminary study of the age at which hemlock growing in good sites should be thinned was made. Where stands are thinned at 15 years to 1,000 trees per acre, the stand at 30 years should average $6.5^{\prime \prime}$ D.B.H. A sound thinning at 30 years to 280 trees per acre should produce a stand averaging $12 "$ D.B.H. at 50 years. Further thinning might produce wood with 7 to 8 rings to the inch for a century. The effect of early thinning on natural pruning is not known and will be determined by experiment thinnings.

\section{Anglo-Bowater's Silvicultural Research Division}

Forest conditions on the limits of the Anglo-Newfoundland Development Company, Ltd., and the Bowater's Nfld. Pulp and Paper Mills, Ltd. are so similar that the two companies considered it desirable to organize a joint Silvicultural Research Division this year and to pool all information thus obtained. Work of the Anglo-Bowater's Silvicultural Research Division commenced in July.

The sustained yield management plans of both companies are due for revision.

The major portion of their limits have been covered by aerial photography within the past two years. These will provide mosaics, type maps and inventory.

The Research Division has undertaken to determine the increment upon which to base the cutting budget. To this end three parties established 550 
permanent sample plots east of the Topsail Mountains. It is proposed to establish a like number on the Western Division limits in 1948 . These will probably be sufficient to complete the project. From the data collected increment will be determined by the following methods:

1. Mean annual increment.

2. Periodic annual increment.

3. Empirical yield tables.

4. Formulae methods.

5. Stated density yield tables.

6. Paired plots, or remeasurement.

Compilation of the first four methods is progressing rapidly. Methods 5 and 6 depend upon remeasurement data five years hence.

A complete set of local form class volume tables have been prepared for use in inventory and increment investigations. These have taken into account factors of form-class, site-type, age-class and density.

Experimental cuttings, both harvest and intermediate, are major projects. It is recognized that there is room for improvement in present cutting methods, both silviculturally and economically.

A number of such investigations have been established in years past. In 1945 there were eight experiments, covering about 1,600 acres in diameter limits cuttings. Plans have been made for other series based on selective cutting. The first of these, 50 acres in extent, was executed this year. Trees were marked to leave a residual stand space at 8 to 10 foot intervals.

A seed tree experiment was started, the purpose to leave five seed trees per acre in an otherwise clear-cut stand.

Sample plots in 20 year old balsam fir thickets were thinned to 4 and 4.5 feet intervals.

Demonstration is the best form of education. A farm woodlot of 300 acres was established last year. The first selection cutting was made this year. It provided for a cut of 100 cords or a third of a cord per acre.

An area of 1,000 acres has been surveyed and cruised for a demonstration working plan. Cutting of annual increment will be made by selection, annually.

Although most burned areas within the limits have reproduced naturally there are a number of reburns, now barren or reproducing to white birch. A study has been started to determine whether these can be reclaimed by direct seeding methods, or whether planting methods must be employed.

First steps have been taken to introduce valuable exotic tree species. There is evidence that such species as red pine, Norway spruce, cedar, yellow birch, hard maple, becch, ash and basswood will thrive in Newfoundland.

Fortunately there is no threat of insect epidemics at present. The possibility of an outbreak of spruce budworm, hemlock looper and larch case bearer, and saw-fly are not overlooked. Through the co-operation of the Dominion Department of Agriculture parasites are being released in large numbers. Consideration is being given to application of silvicultural methods as means of control. 


\section{Manitoba and Saskatchewan}

\section{Regeneration Survey}

A party engaged in the study of regeneration on cut-over and burnedover lands operated in the Province of Saskatchewan. A total of 1,325 plots were established.

\section{Rate of Growth Survey}

A Rate of Growth Survey was carried on at the Riding Mountain National Park. An area designated for silvicultural research was sampled by approximately 450 permanently established sample plots.

3. Reproduction Cutting Survey

Ten areas, each ten acres in size, were selected for different silviculturaI treatments. Ploughing in parallel strips was done in each area, using the Athens disc-type plough. It is proposed to cut each area by a different system of logging and at subsequent dates remeasure the residual stands to study increment and reproduction.

\section{Working Plan Survey}

A working plan survey was carried out on the Riding Mountain. This was to revise the data gathered on the same area ten years ago. This was a joint project between the Aerial Surveys Division and a field party doing ground work.

\section{Regeneration Party}

A party on the Duck Mountain investigated the amount and condition of reproduction on stands that have previously been subjected to different silvicultural treatment.

\section{Heart Rot of Aspen}

Data were collected to correlate the heart rot of aspen with age and diameter of the trees. This project is still incomplete.

\section{Phenology}

Phenological records were kept of the representative plants in this district.

\section{Alberta \\ 1. Regeneration Survey-Phase 1}

This was a fact-finding survey to find out the amount and kind of natural regeneration following cutting and fire in this Province. In 1946 the party covered the Subalpine Forest Region from the U.S. border along the East slope of the Rockies to the main line of the C.N.R. west of Ed. monton. In 1947 this work was extended to cover the western end of the Boreal Forest Region from Lesser Slave Lake south to the Red Deer River. The data have not yet been compiled.

\section{Regeneration Survey-Phase 2}

This party was engaged in studying the underlying causes effecting regeneration, or the lack of it, on cut and burned over lands. Since, following fire, there is usually no lack of lodge-pole pine regeneration if a seed supply is present, this investigation was mostly engaged in studying the problem of spruce regeneration on cut-over lands. Fundamental methods are being used in this study to determine the causes of phenomena as observed and the treatment required to obtain desired results. 


\section{Regeneration Studies (Seedbed Treatment)}

This is a study, by empirical methods, of various cultural treatments of seedbeds to induce regeneration of desired species, in this case spruce and pine, in three kinds of stands, namely, cut-over spruce stands, undisturbed pine stands (where an understory of spruce is lacking) and in mixed poplarspruce-Douglas fir stands. Some of the cultural treatments being tested are:

(1) Controlled burning

(2) Athens disc plow

(3) Machine packing

(4) Various combinations of the foregoing.

One project, in which a tractor and bulldozer were used in a mixed stand of poplar and spruce, achieved outstanding initial success, as many as 545 cotyledenous seedlings being counted on one milacre plot. Survival was good over the first season but the experiment cannot be termed a complete success until several years have passed and the number of established seedlings determined.

\section{Soll Survey}

A detailed soil survey of the Kananaskis Forest Experiment Station is being undertaken.

\section{WORkINg Plan Survey}

A Working Plan Survey of the Kananaskis Forest Experiment Station was started in 1936 at which time about one thousand yield plots were estab. lished on the area. In 1946 these were remeasured and the growth data compiled. This work was continued in 1947.

\section{Fire Hazard Research}

This work, started in 1939, was continued and sufficient data collected to prepare reasonably accurate and reliable curves for this region.

7. EMPIRICAL THINNINGS AND NORMAL YIELD

Starting in 1936 many permanent sample plots were established on the Kananaskis Forest Experiment Station for the purpose of studying the effects of various kinds and degrees of thinning. In conjunction with these, control plots were also established to determine normal yield. Most of these plots have now been measured a second time, some of them a third time, and much valuable data collected. Athough the compilation of these data is not completed in many cases, sufficient has been done to make possible the publication of conclusions in connection with a number of these experiments.

\section{Phenological and Weather Records}

These have been carried on since the establishment of the Kananaskis Forest Experiment Station in 1935.

\section{Maritime District Off
Green River Management Project}

Through the cooperation of Fraser Companies, the New Brunswick Government, the Pulp and Paper Association, and the Dominion Forest Service, the Green River Project was established in 1945. This project is primarily intended to develop a management plan for a pulpwood forest that would lead to success in controlling the spruce budworm. 
In connection with the long-term study, five 4,000-acre research blocks are to be established-three of these are completed. These blocks are of a permanent nature and have established within them a series of small permanent sample plots which will make possible from future examinations the reaction to the system of cutting used in regard to the control of this insect. Because of the lack of inventory information it has been impossible to write a management plan for the 400 square miles in the area, but as a pre. liminary plan it has been decided to carry out what might be termed presalvage operations-in these operations all over-mature stands of balsam which are susceptible to the budworm infestation are being removed as quickly as possible.

In addition to the budworm studies, short-term projects of interest to the pulp and paper industry are being carried out-these include selective cutting on pulpwood stands, utilization studies, and windthrow studies. It is ex. pected that other studies will be added as time goes on so as to make the project of the greatest possible value to the pulpwood industry.

The 4,000-acre research blocks are designed for re-examination at 5-year intervals and will provide much information vital to long-term management plans.

During the past year the third block was established and considerable general reconnaissance work was carried out to provide additional ground control to be utilized in connection with production of new forest maps and estimates. A party of eighteen University of New Brunswick students, under the direction of D. E. Nickerson, was responsible for the work in this area.

Reproduction Survey

A party under the direction of Cameron Place investigated cut-over areas in New Brunswick and Nova Scotia in connection with regeneration study. This year's work was primarily centred on burned-over areas. The work of the first phase of the reproduction study was completed in the Maritime Provinces this year; this phase had to do with the collection of data which would give a lead as to the necessary studies to be inaugurated in the second phase of the study in an endeavour to discover how to obtain satis. factory reproduction on areas not presently reproducing following cutting or burning.

\section{Growth Studies}

In 1927 a series of sample plots was established on the Miramichi drain. age area to study growth, mortality and reproduction in spruce balsam stands. These plots were examined during the past summer.

Bathurst Experimental Cutting Area

Final examination of this area, which was cut over in 1916 was made utilizing extensive chain-wide transects. As the area in question was clearcut during the period 1916-1920, it was hoped to obtain valuable data in respect to reproductive possibilities of such cut-over areas.

U. N. B. Permanent Sumple Pluts

Permanent sample plots established on the University of New Brunswick woodlot in 1937 were examined to study effects of thinning. 
Farm Woodlots

Following a request made by the Dominion Department of Agriculture, the Dominion Forest Service established thirteen managed woodlots on Dominion Experimental Farms or Agricultural Illustration Stations throughout the Maritime Provinces. These woodlots were under the direction of the Dominion Forest Service and management plans were prepared for them. These areas were examined during the past summer and marking of trees for future cutting was carried out by a Forest Engineer from this office.

Prince Edward Island

During the season of 1937 a series of demonstration woodlots were established on Prince Edward Island; the purpose of the establishment of these woodlots was to demonstrate to P.E.I. farmers the possibilities of growth through management of their wooded areas. 53 pairs of plots, distributed well over the Island, were laid out, one plot of each pair being thinned. Data are collected at each remeasurement for the development of growth studies and the thinned area is marked where necessary for further cutting. Details of all material removed are kept.

The purpose of the work is to encourage the management of the woodlots on the Island on a sustained yield basis.

\section{Working Plan Survey}

ACAdia Forest Experiment Station

To make possible the future development of this area, and to have per. manent data in regard to the stands, a system of permanent line plots is being established. These line plots will make possible future examination of any area under any circumstances and will allow comparison with the data compiled at the time of establishment. Plots will be particularly useful for the study of growth and yield. 16 square miles of the Station area are now covered by this line plot system.

Plantation Studies

Considerable work was carried out in connection with results obtained from planting various species on the Acadia Station area.

\section{Permanent Sample Plots}

A number of permanent sample plot projects were remeasured during the 1947 field season. These dealt mainly with intermediate cuttings in young and relatively even-aged stands.

Nursery

Nursery work at the Acadia Station has been extended somewhat in an endeavour to assist the New Brunswick Government through the supplying of planting stock. During the planting season approximately $65,0002.0$ stock was put in transplant beds. 28 nursery beds were established, 14 of which are to supply future material for the New Brunswick Government.

In connection with our planting program on the Acadia Station four small plantations were made, a total of approximately 5,000 transplants being utilized for this purpose. These plantations have to do primarily with species investigations and survival studies.

Reports in connection with all investigations examined during the past summer are being prepared, and will be available to interested parties. 


\section{SURVEYS}

During the year 1947 the following information was made available to the Surveys Research Committee: follows:

H. J. Hodgins of Pacific Mills Limited, Vancouver, B.C., reported as

"We mentioned that we were considering making detailed logging maps from vertical air photographs. This year we are actually preparing logging topographical maps on a scale of $400 \mathrm{ft}$. to the inch with $20 \mathrm{ft}$. contours. This work is being done with a very limited amount of control by a commercial firm. The indications are that they can supply a finished map suitable for truck logging operations in typical West Coast terrain and maintain an accuracy of about $10 \mathrm{ft}$. in elevation. Horizontal control, I believe, will be just about perfect. This work is being done at a ridiculously low price compared with the normal ground survey procedure."

Some notes on the work of the Forest Air Survey staff of the Dominion Forest Service are as follows:

"The first instance of the practical application of the forestry tri-camera method of air photography in its fully developed stage occurred during the year in the form of the photographing of the Riding Mountain National Park, which was carried out under winter conditions on the recommenda. tions of the Dominion Forest Service, whose duty it was to prepare the forest inventory maps. This was immediately followed by similar photography as requested by the Dominion Forest Service in the Parent region, Province of Quebec, the total coverage of the two operations being about 2,800 square miles.

"Forestry tri-camera photography has been developed as a result of the efforts of the Dominion Forest Service to establish a method of air photo. graphy which will meet the special needs of the forester for a maximum of forest detail at a minimum of cost in circumstances where it has become necessary to re-photograph in order to determine the changes that have taken place in the forests or to obtain other additional information. The method owes its importance to the detailed research which has been conducted in respect to the forestry value of various kinds of photographs rather than to the consequent arrangement of cameras and other particulars of photography. Advantage has been taken of the fact that the comparatively rigid requirements of air photography for basic mapping are not necessary in the field of forestry.

"The forestry tri-camera photographs that have been taken during the year have demonstrated both the economy of operation and the clarity of detail that are possible with this new method of photography. Incidentally, it was demonstrated that both hardwoods and softwoods can be photographed to best advantage during the winter. The maps and estimates which are being made have thus far given a very favourable indication of the applied value of the method.

"Detailed maps covering about 100 square miles in the Upper Mitch. inamekus region, Province of Quebec, were prepared in order to test the 
application of detailed quantitative estimating of pulpwood stands as carried. out by means of air photographs as taken by the forestry tri-camera method.

"The work of gathering data in the field in support of quantitative estimating of the forests was preceeded with, and valuable information was obtained in regard to quantities corresponding to various heights of stand and to various degrees of crown closure. Furthermore, some very significant data were obtained in the field with reference to the determination of diameter of bole from height and crown width as measured in the photo. graph."

During the period from January 1, 1948, to September 14, 1948, the following information became available to the Survey Research Committee.

The Associate Committee on Forestry of the National Research Council called a meeting in Ottawa on February 6, 1948, with the aim of obtaining advice on the question of securing maximum forestry information from air photographs. The meeting was to some extent a sequal to a similar meeting which had been held about a year previously by the Woodlands Section of the Canadian Pulp and Paper Association.

It was decided to investigate matters of scale, season of the year and printing media and consequently the problems were placed before the Associate Committee on Photographic Research of the National Research Council, from whom most valuable information will undoubtedly be received.

From the Air Survey staff, Dominion Forest Service, it has been reported that two leaflets have just been published, which may be of interest.

Forest Air Survey Leaflet No. 1, entitled, "The Pole Scale," describes a device which has been found to be particularly applicable in the measurement of fine tree images in the air photographs.

\section{The Pole Scale ${ }^{1}$}

Certain measuring devices, such as the Tree Height Grid and the Wedge Scale, which have been designed and employed by the Forest Air Survey Division of the Dominion Forest Service for the measurement of fine tree images in air photographs, have a disadvantage in that the lines which are used for measuring purposes have an obscuring effect at the top and base of the tree's image. In other words, if the tree's image is measured while in a position where it spans the distance between two delimiting lines (see Fig. 1), these lines will often obstruct and distract the view and prevent the greatest speed and accuracy of measurement, especially during stereoscopic examination. The difficulty could not be overcome by making the lines extremely fine, for not only would it be impracticable to do so by present methods, but also the lines must be heavy enough to be clearly visible.

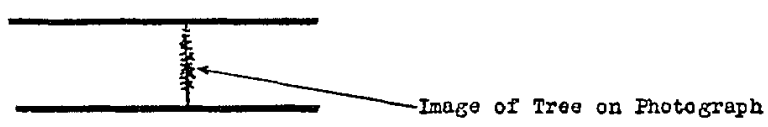

Fig. 1

1 Dominion Forest Service "Forest Air Survey Leaflet No. 1" by H. E. Seely. 
In order to overcome the difficulty, the so-called "Pole Scale" (Fig. 2), in which small lines of various lengths are employed, has been devised by the writer. It is possible to match these small lines or poles with a tree's image and to select the particular pole that most nearly compares with it in length.

Fast and accurate measurement is facilitated because of the construction of the Pole Scale: the individual poles are also particularly distinct to the eye, owing to the effect of movement during the process of adjustment to the tree's image. A further advantage lies in the manner in which the pole may be aligned with the axis of the tree's image. This is important in the case of a tree whose foliage obscures its base, making it necessary to estimate the position of the point of juncture of the image and the tree's shadow. There is also a natural ease of comparison between the poles and the tree images because of their common linear character. Furthermore a slender measuring device offers the least possible obstruction to the view in the measurement of closely grouped tree images. The Pole Scale as shown in Fig. 2 not only contains poles for measuring the length of tree images but aiso provides a few additional small poles for measuring the crown widths.

The question of the stereoscopic fusion of two poles for the purposes of measurement of tree images has not yet been investigated in detail.

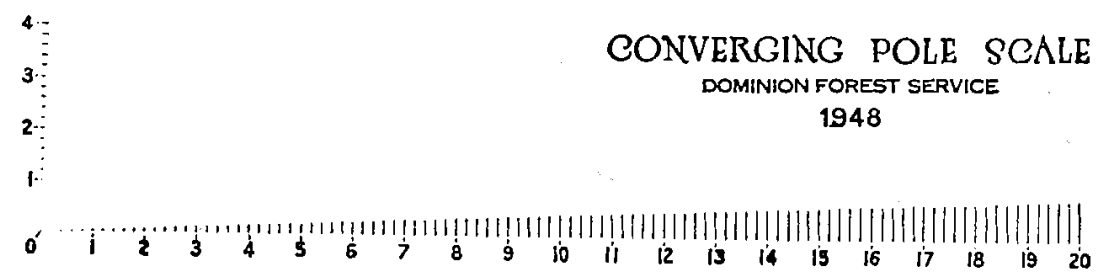

Fig. 2

A disadvantage of the Pole Scale as shown in Fig. 2 is that it requires the use of a converting factor in order to determine the tree's height. It is merely a measuring device like a foot rule and does not take into account the varying scales of the tree images. Special pole scales will therefore be constructed for both vertical and oblique photographs, in which the poles will be of the correct size for direct measurement. However, it will be necessary to reduce greatly the number of poles which may be selected for the measurement of any particular tree's image, and accordingly the original pole scale will remain the best device for the accurate measurement of individual trees. On the other hand it is usually the general height of the stand which is to be determined, in which case the special pole scales will be far more applicable on account of the speed with which a great number of trees may be measured in a short time.

In the construction of special pole scales for oblique photographs, use would be made of the mathematical solutions as employed in the construction 
of the Tree Height Grid, Fig. 4(a), which was originated by the writer in the pre-war years. Like the special pole scales the Tree Height Grid takes the scale of each tree's image into account. It has been constructed for use on various oblique photographs and consists of parallel lines spaced at intervals representing 100 feet of tree height. It is not expected that it would be entirely superseded by the special pole scales, because it will always be valuable for a rapid assessment of tree heights.

In oblique photographs truly vertical objects appear inclined in the direction of the plumb point, because, by the laws of perspective, parallel lines meet in a vanishing point. Accordingly, it is desirable, in drawing the special pole scale, to incline each pole to coincide with the axis of the tree's" image. See sample photograph, Fig. 3.

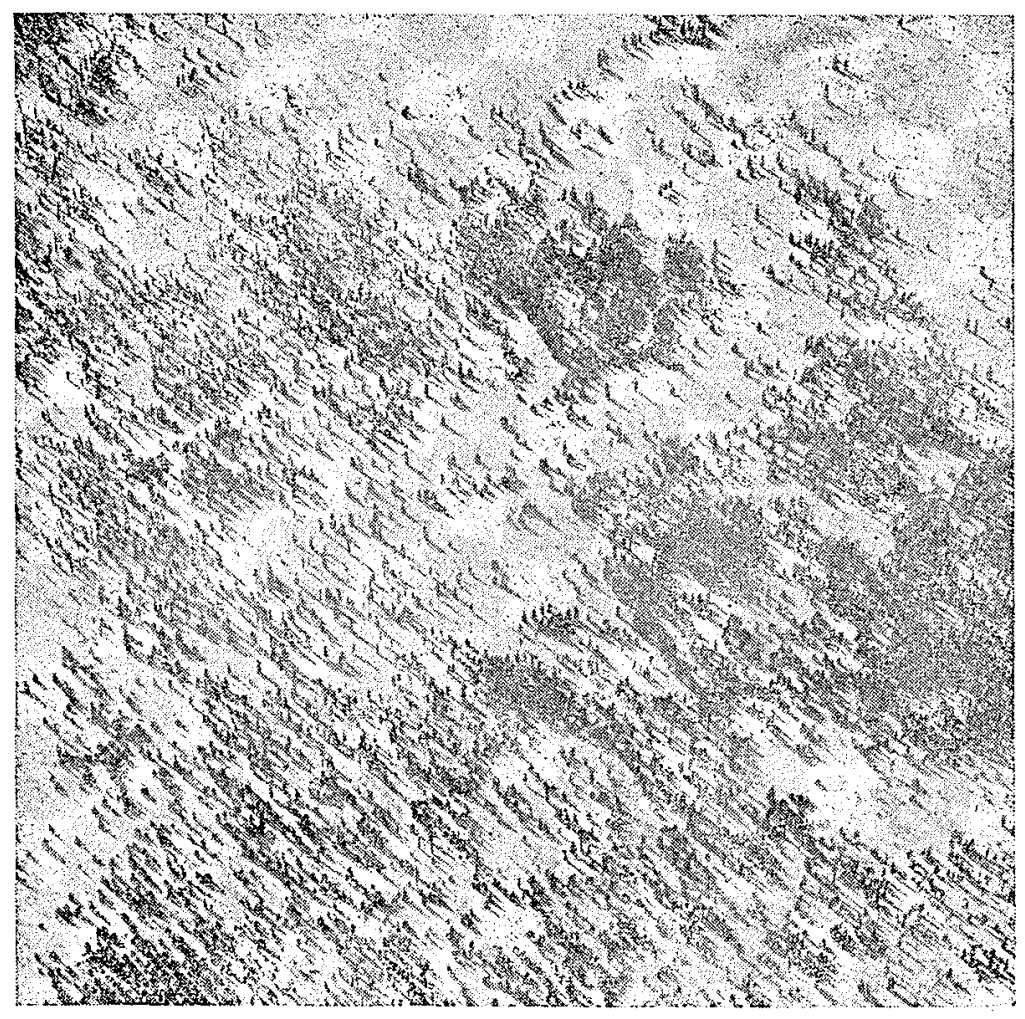

Fig. 3

Oblique Air Photograph

It may be found convenient in some cases to employ composite poles for use in special pole scales. In Fig. 4(b) proposed composite 100-foot poles are shown, each consisting of three 20 -foot poles, together with two 
intervals of 20 feet each. The individual portions of the composite poles would act as graduations to aid measurement in cases where space does not permit the employment of numerous poles of various lengths.

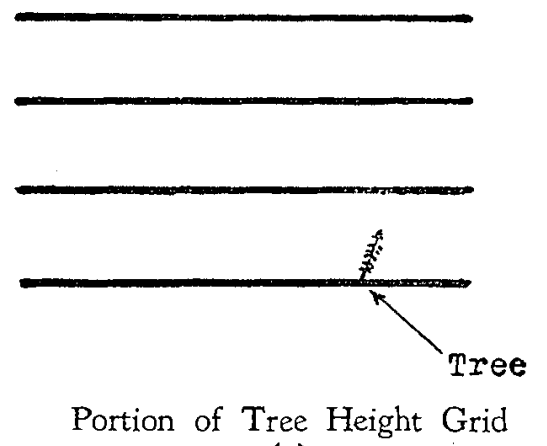

(a)

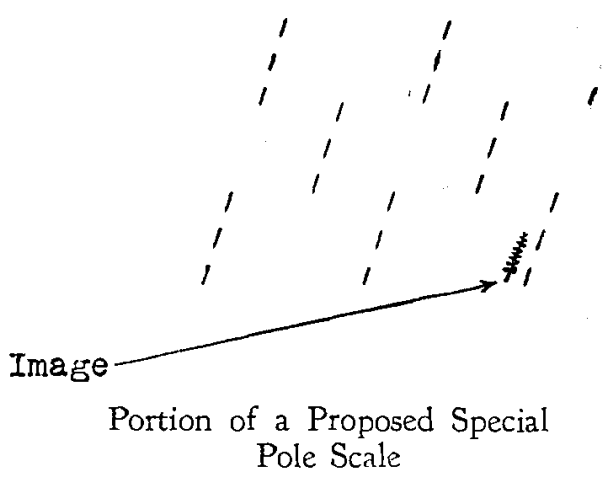

(b)

FIG. 4

The pole scales may of course be applied to the measurement of shadows as well as of tree images in the air photographs.

Forest Air Survey Leaflet No. 2 deals with the Shadow Height Calculator. This device has been constructed in order to simplify the calculations which are required in the shadow method of determining tree heights in air photographs. Answers which previously necessitated lengthy computations may now be obtained instantaneously.

Incorporated in this calculator is an adaptation of a centuries-old device known as the "Mathematicall Jewell", a description of which may be found in "Astrographics" by Frank Debenham, Professor of Geography at the University of Cambridge.

The Dominion Forest Service of the Mines, Forests and Scientific Services Branch, Department of Mines and Resources, Ottawa, has pioneered in the preparation of general forest inventory maps which are reproduced in full colour by photolithographic processes and in which the classification of the forests is done largely by air photographs. This new departure, the inception of which was made possible by the co-operation of the Army Survey Establishment, Royal Canadian Engineers, Ottawa, is of particular importance because it enables quantity production of maps in full colour. This is of importance because of the special value of colour in differentiating the vari ous forest classifications. The maps, as recently standardized, show the forest classified according to type, crown closure, and height, these being the values which are most readily determined from the air photographs. The maps are printed on a scale of one mile to one inch and some two dozen have been published as samples in various regions. Broad estimates of timber quantities can be derived from such maps by means of available data. If supplemented by field information covering species, quality, age and site, the maps will provide a comprehensive picture of the forest conditions. 
The actual carrying out of the operations which are involved in the preparation of forestry maps by this new system has provided a full demonstration of its advantages. The procedure is faster than in the case of the ordinary method of preparing tracings and printing on sensitized paper because advantage is taken of prints made from the existing plates as prepared for the purposes of the National Topographical Series of published map sheets. Thus the draughtsman is not forced to re-draw and re-letter the base map. Furthermore, a similar saving is introduced in the colouring of the maps whereby in a single step colour plates are made which will serve for thousands of copies, whereas a corresponding step must be carried out, in the case of hand colouring, for each additional copy. Finally quantity production of map sheets becomes possible because of the relatively negligible cost of supplying at least one thousand additional copies off the press in full colour on lithographic paper. Incidentally, it may be mentioned that lithograph paper is superior in point of durability, appearance, shrinkage and fidelity in reproduction of detail. At the same time, the photolithographic processes provide a superior uniformity in colouring.

\section{H. E. Seely, Chairman \\ W. Ross Grinnell, Secretary}

Through the courtesy of the Dominion Forest Service a sample map has been distributed to members of the Society with this issue of the "Forestry Chronicle."

\section{WOOD ULITIZATION}

An outstanding development in the field of wood utilization in 1947 was the expansion of the pulp and paper industry in Canada. In most instances this was accounted for by increasing the capacity of existing mills, though in some cases this also involved a greater diversity of products. A few developments of particular interest are worthy of special note.

The Abitibi Power and Paper Company, Ltd., completed the construction of, and put into operation, the first semi-chemical pulp-mill in Canada and the first of its particular kind in America. This plant has a capacity of about 100 tons a day of liner board or similar products.

Fraser Companies, Ltd. were in the process of constructing a kraft mill at the mouth of the Miramichi River with the primary objective of using sawmill by-products as a principal form of raw material. On the West Coast, too, more attention was being paid to the utilization of sawmill waste. The new 200-ton kraft-pulp-mill of Bloedel, Stewart, and Welch, Ltd., at Port Alberni, went into production. This mill uses considerable quantities of round wood, but also the by॰products of other wood-using plants in the vicinity.

By the end of the year some other new pulp-mills were in prospect for the coastal region of British Columbia, and negotiations were in progress for at least one pulp-mill in Alberta.

One or two small hardboard plants were also in prospect in British Columbia. Formerly it was considered that building board could not be produced in small plants because of the high capital investment involved 
per unit of output. A new manufacturing plant at Corvallis, Oregon, produces by a new procedure hardboard in quantities as small as seven or eight tons per day. Essentially, the process is one of mechanical defibering the wood, mixing it into a slurry, forming on a wire and hot-pressing. Negotiations were in progress for the manufacture of "Chapman" board in Canada.

During the year another United States pulp-mill went into the manufacture of alcohol from waste sulphite liquor, namely, the Puget Sound Pulp and Paper Company, and a new plant is under erection in Canada by the Canadian International Paper Company. The alcohol plant at Springfield, Oregon, concluded its preliminary trials of the manufacture of alcohol direct from wood waste, and was put up for sale to commercial interests. The problem of profitably marketing the residual lignin, or even of disposing of it satisfactorily, is not yet solved. Yields of alcohol have not quite come up to expectations.

By the year's end, the first pulp-mill in America to make use of the magnesium sulphite process was nearing completion at Longview, Washington. This and a kraft mill at the same site will operate, in part at least, on sawmill by-products and low.grade logs. Also on the West Coast rapid headway is being made in the development of hydraulic barkers, both for logs and for sawmill by-products. The Puget Sound Pulp and Paper Company has developed two machines, one capable of barking logs ranging from 6 inches to more than 6 feet in diameter, the other removing bark from sticks as small as one inch square in cross. section and less than one foot long.

Considerable advances were made in the use of high-frequency dielectric heating, particularly in the field of wood gluing. A number of new machines were placed on the market, at least one of them operating on the continuous flow principle of producing glued up coresstock. The Forest Products Laboratory, Ottawa, has carried out extensive work in this field.

A significant development in the field of research in wood utilization was the formation of the Forest Products Research Society, an organiza. tion devoted to the exchange of research information and related activities. By the year's end, the Society had a membership roll of approximately one thousand drawn from all part of the United States and Canada, and a few from other parts of the world.

A good deal of attention was given by the Forest Products Laboratory, Ottawa, to the investigation of the use of bark of spruce, pine, cedar, etc., and particularly to its use in the manufacture of hard and soft boards. The work is being extended to mixtures of bark and wood waste in varying proportions for board. Special equipment for this work has recently been installed.

An interesting development was the establishment of a Weyerhaeuser plant at Longview, Washington, for the manufacture of products from 
the bark of Douglas fir. These products include fillers for moulding compounds, a soil conditioner, a glue extender, a vehicle for insecticides, and many similar uses.

The use of laminated timber in construction is progressing rapidly. Glued laminated arches are being used extensively in the construction of barns, garages, skating rinks, and other industrial buildings. In co-operation with the railroads, the Forest Products Laboratory has build a number of laminated railway ties, supplying the heat for bonding the glue in the joints by a high-frequency dielectric unit of $71 / 2$ H.P. output capacity. The ties have been installed in track for long service test. A 47-foot span laminated arch, built by the Laboratory, has also been under loading tests for about a year. This type of construction shows much promise with the increasing difficulty of obtaining large structural timbers.

The increasing cost of stumpage and plant operation have caused a large increase in the cost of lumber and, consequently, a good deal of interest in developing methods of sawing which will permit the production into lumber, economically, of a higher percentage of the sawlog volume. Studies have been in progress by the Forest Products Laboratories in Eastern Canada and British Columbia of methods of operation and of equipment in sawmills as a basis for improvement. This work is being carried out in close co-operation with industry.

A Building Research Division has been organized in the National Research Council which should do much to improve building construction and develop standards in the building trades. The division will have charge of the revision of the National Building Code of 1941 and of keeping it up-to-date by periodic revision as new techniques of construction develop and new building materials become available.

On account of increased demand for electric power and telephones in industrial and rural development, there has been urgent demand for telephone poles. The Canadian Standards Association has got out during the year revised specifications for pine poles and issued a specification for Douglas fir poles.

A paper on "Widening Uses of Wood Waste" was prepared by the Forest Products Laboratory for the Annual Meeting of the Technical Section of the Canadian Pulp and Paper Association. This paper was published in the No. 3 Edition, Convention Issue, of the Pulp and Paper Magazine, 1948. It contains a good deal of information additional to that included in this brief report, particularly in relation to the chemical utiliza. tion of wood waste.

At the Forest Products Laboratory, Ottawa, in September, 1948, a Conference on Timber Mechanics was held of representatives of different forest products laboratories of the British Commonwealth. Delegates attended from Great Britain, Australia, South Africa, New Zealand, and the Federated Malay States. Representatives of the U.S. Forest Products Laboratory also took part in the Conference.

T. A. MCEI HANNEY, Chairman

E. S. Feliows, Secretary 